\title{
Tectonics of the Monte Rosa and surrounding nappes (Switzerland and Italy): Tertiary phases of subduction, thrusting and folding in the Pennine Alps
}

\author{
Albrecht Steck ${ }^{1} \cdot$ Henri Masson ${ }^{1} \cdot$ Martin Robyr $^{2}$
}

Received: 6 May 2014 / Accepted: 11 February 2015

(C) Swiss Geological Society 2015

\begin{abstract}
The Monte Rosa basement fold nappe, surrounded by other continental units of the Briançonnais s.l. domain and ophiolites of the Piemont Ocean, represents a major structure of the Pennine Alps situated at the border of the Canton Valais (Switzerland) and Italy. The Central Alps were formed during the collision and SE-directed underthrusting of the European below the Adriatic plate by successive underthrusting, detachment and accretion of the Austroalpine Sesia continental crust, the Piemont oceanic crust and the continental Briançonnais-Europe plate border. The 90-60 Ma Sesia high-pressure metamorphism, followed by the 50-38 Ma Zermatt-Saas Fee and Monte Rosa high-pressure metamorphism, and since $40 \mathrm{Ma}$ by the Barrovian regional metamorphism, reveal a long-lasting Alpine evolution during convergence of both plates. The superposition of the ultra-high pressure Zermatt-Saas Fee ophiolites by the continental Cimes Blanche unit of the Briançonnais domain and the medium pressure ophiolitic Tsaté nappe is explained by delamination and tectonic flake detachment of the Cimes Blanches from the Briançonnais crust and its south directed thrust over the Zermatt-Saas Fee and Tsaté ophiolites. The main ductile deformational structures, related to the NW-directed nappe emplacement, were generated after $40 \mathrm{Ma}$ under greenschist to amphibolite facies Barrovian orogenic
\end{abstract}

Editorial handling: A. G. Milnes.

\footnotetext{
Albrecht Steck

albrecht.steck@unil.ch

1 Institut des Sciences de la Terre, Géopolis, Université de Lausanne, 1015 Lausanne-Dorigny, Switzerland

2 Institut für Geologie, Baltzerstrasse $1+3,3012$ Bern, Switzerland
}

metamorphism. Early extrusional structures have been transposed by the younger thrust structures. The NW-directed thrust of the Alps was accompanied since about $35 \mathrm{Ma}$ by ductile dextral shear and backfolding in the zone of dextral transpression between the converging European and Adriatic plates.

Keywords Switzerland · Italy · Central Alps · Tertiary fold nappes · Alpine orogeny

$\begin{array}{ll}\text { Abbreviations } \\ \text { Ant } & \text { Antrona ophiolitic unit } \\ \text { Be-Ru } & \text { Berisal-Ruginenta } \\ \text { CB } & \text { Cimes Blanches } \\ \text { DB } & \text { Dent Blanche } \\ \text { 2 DK } & \text { Seconda zona diorito-kinzigitica } \\ \text { Fu } & \text { Furgg } \\ \text { Go } & \text { Gornergrat } \\ \text { MR } & \text { Monte Rosa } \\ \text { Por } & \text { Portjengrat } \\ \text { Se } & \text { Sesia } \\ \text { SM } & \text { Siviez-Mischabel } \\ \text { Ts } & \text { Tsaté ophiolitic unit } \\ \text { Tu } & \text { Tuftgrat } \\ \text { Va } & \text { Valpelline } \\ \text { ZH } & \text { Zone Houillère } \\ \text { ZS } & \text { Zermatt-Saas Fee ophiolitic unit }\end{array}$

\section{Introduction}

The Monte Rosa unit is a recumbent gneiss fold nappe of the Penninic zone of the Central Alps exposed in the over $4000 \mathrm{~m}$ high mountain range at the border of Switzerland 
and Italy (Figs. 1, 2, 3, 4). The geological investigation of the Monte Rosa nappe started in the 20th century by the famous works on the Pennine Alps by Argand (1911, 1916) and Hermann (1937). Argand defined the gneiss fold nappes of the Pennine Alps after the discovery of the nappes of the Central Alps by Schardt (1903) during the perforation of the Simplon railway tunnel. Geological mapping of the six map sheets at a scale of 1:25,000: St. Niklaus, Simplon, Randa, Saas, Zermatt and Monte Moro by Bearth $(1953,1954 a, b, 1964,1972,1978)$ and Matterhorn by Bucher et al. (2004) laid a solid framework for future geological studies. Bearth (1939, 1952, 1956, 1957a, b, 1958, 1962, 1967, 1973) discovered and described, in his study of the Monte Rosa region the high-pressure regional metamorphism followed by the Barrovian metamorphism of the Central Alps. Dal Piaz et al. (1972) discussed the tectonic evolution and Eoalpine high-pressure metamorphism of the Monte Rosa-Piemont Ocean-Sesia transect. Gosso et al. (1979) proposed a structural model of the Monte Rosa nappe. Milnes et al. (1981) analysed the interference pattern of post-nappe folds and concluded by a model of the nappe stack. Lacassin (1984), (Lacassin and Mattauer 1985) discovered a kilometre-size NW-directed sheath fold in the Gornergrat zone at the roof of the Monte Rosa nappe and estimated a displacement of $20 \mathrm{~km}$ for a $1 \mathrm{~km}$ wide shear zone. Sartori $(1987,1990)$ presented a detailed study of the structure and stratigraphy of the Combin zone, followed by a synthesis of the structure and stratigraphy of the Grand Saint-Bernhard nappe by Escher (1988). Dal Piaz (2001) wrote a historical review of the geology of the Monte Rosa massif completed with personal comments. Pleuger et al. $(2005,2008)$ propose a model of the complex Alpine structural evolution of the Monte Rosa nappe. The metamorphic evolution of the Zermatt-Saas Fee ophiolites and Monte Rosa basement nappe have been investigated by Bearth (1967), Dal Piaz (1992, 2001), Meyer (1983), Barnicoat and Fry (1986), Ganguin (1988), Pfeifer et al. (1991), Colombi (1989), Cartwright and Barnicoat (2002), Pawlig and Baumgartner (2001), Engi et al. (2001, 2004) and Bucher et al. (2005). The radiometric dating of the 50-38 Ma high- to ultra-high-pressure metamorphism of the Zermatt-Saas Fee unit (Gebauer 1999; Amato et al. 1999; Engi et al. 2001, 2004; Lapen et al. 2003; De Meyer et al. 2014) followed after $40 \mathrm{Ma}$ by the medium-pressure Barrovian metamorphism of the Central Alps (Frank 1983; Hunziker et al. 1992; Markley et al. 1998; Engi et al. 2001; Janots et al. 2009) reveal a long lasting and complex structural evolution by deep underthrusting, extrusion and younger ductile folding and thrusting. Numerous masterstudies by students of the University of Lausanne investigated the geology of the Monte Rosa and its surrounding units. The Middle Penninic units of the Valais Alps have been described in Escher (1988), Escher et al. (1997), Steck
Fig. 1 Structures of the Central Alps, modified after Steck (2008), Steck et al. (2013), Tektonische Karte der Schweiz (2005) and Cavargna-Sani et al. (2014). The Monte Rosa nappe is situated at the western border of the Lepontine tectonic half-window. $C L$ Centovalli line, $M F L$ Malenco-Forno-Lizun nappe, $R K G$ Rote Kuh-Gampel fault, $2 D K$ Seconda zona diorite-kinzigitica, $\mathrm{ZH}$ Zone Houillère; (1) Monte Leone basement, (2) Mesozoic and Paleogene sedimentary cover of the Monte Leone, Campo Tencia, Adula and other lower Penninic nappes, (3) Pizzo del Vallone nappe, (9) Brusson window, (10) Canavese Permian-Liassic sediments, (11) Scaredi unit (amphibolite facies grade Ivrea basement), (12) Chiavenna ophiolites, (13) Salarioli Carboniferous-Triassic sediments, (14) Tuftgrat Mesozoic cover of Stockhorn basement, (15) Teggiolo Mesozoic-Paleogene cover of Antigorio nappe, (16) Mesozoic cover of Portjengrat unit, (17) Cristallina Mesozoic cover of Sambuco basement, (18) Bosco unit, (19) Mesozoic-Paleogene Briançonnais cover, (20) StaldenBerisal-Ruginenta basement, (29) Geisspfad peridotite, (30) Cima d'Agaro peridotite, (31) Moncucco peridotite, (32) Albogno peridotite, (33) Finero peridotite. Note on the Simano nappe: Recent work by the authors has demonstrated West of the Ticino river the subdivision of the classical Simano nappe into two tectonic units of different origin, called Verzasca and Campo Tencia. The prolongation of this separation East of the Ticino is still uncertain and for this reason we provisionally maintain the name Simano

et al. (1999, 2001), Sartori et al. (2006) and Steck (2008). The Mont Fort, Ruginenta, Portjengrat, Camughera, SiviezMischabel units and the Zone Houillère are subdivisions of the Grand Saint-Bernard nappe of Argand (1911). These continental units are, together with the Monte Rosa nappe attributed to the Briançonnais (sensu lato) paleogeographic domain limited to the north by the Valais basin and to the south by the Piemont Ocean (Trümpy 1980; Escher 1988; Sartori et al. 2006). The Swiss National Foundation Project 20, reflexion seismic survey of the Zweisimmen-Zermatt and -Mattmark transect performed new data on the deep geological structures of the Central Pennine Alps (Fig. 4; Marchant et al. 1993; Steck et al. 1997). Recent personal field survey during the revision of the 1:25,000 map sheet Saas of the Swiss geological Survey, originally mapped by Bearth (1954a, b), led the authors to reconsider the Alpine structural framework and to propose an updated description of the Monte Rosa and surrounding units and to conclude on a model of their structural evolution based on lithological, stratigraphic, structural, metamorphic and radiometric age data (Figs. 2, 3, 4; Table 1). The crucial point of our fieldwork was the distinction and description of the different tectonic units and their stratigraphy exposed in the Monte Rosa transect of the Penninic Alps. The following main questions are discussed in this study:

1. Which stratigraphic observations permit the reconstruction of the paleogeography preceding the Alpine continental collision of Europe and Adria?

2. Which metamorphic and radiometric data constrain the Alpine tectonic history?

3. Which deformational structures and geometric features explain the Alpine tectonic evolution? 


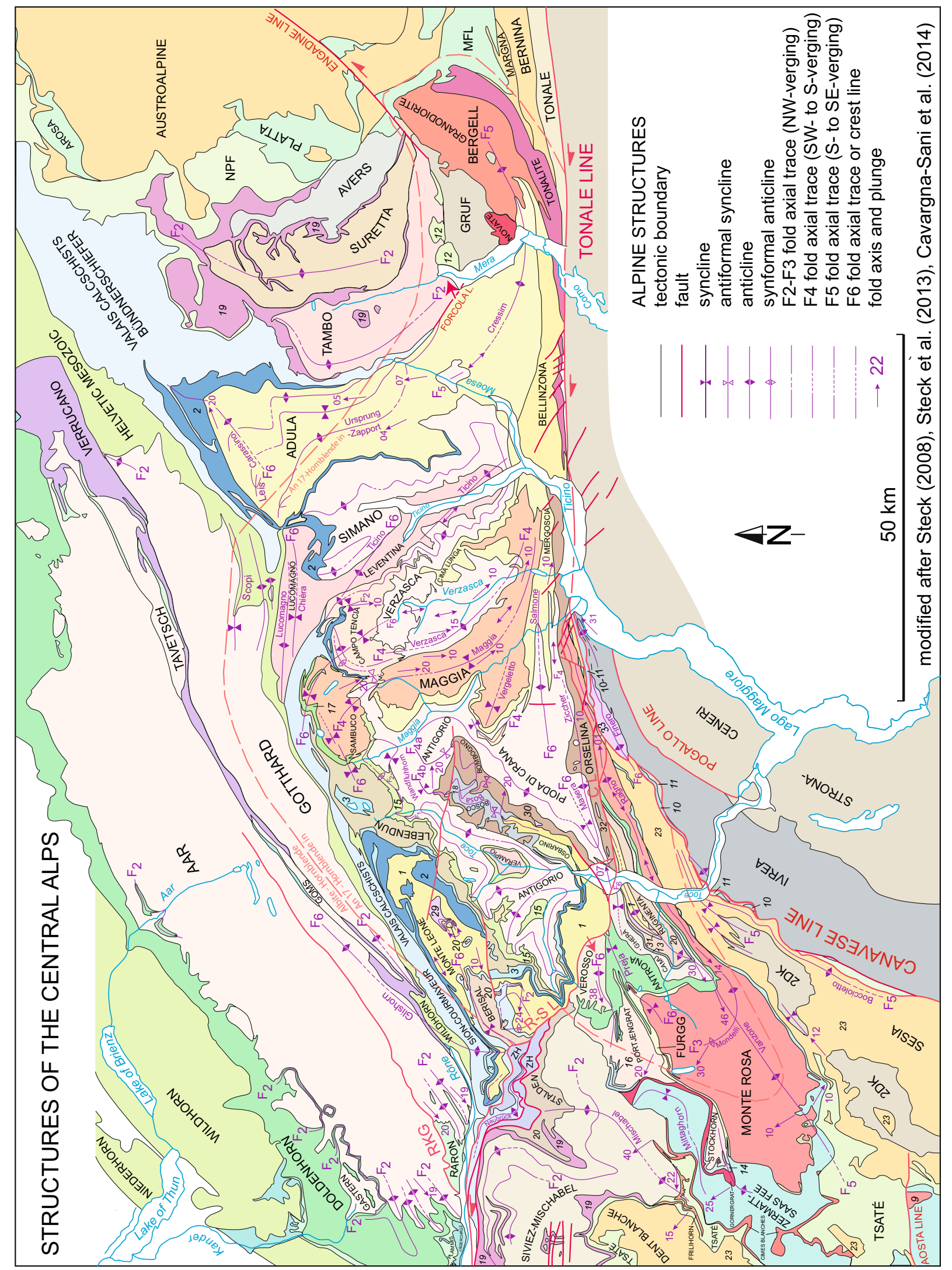




\section{Lithological description of the tectonic units}

\subsection{The Monte Leone nappe}

Steck (2008) divides the Moncucco unit of Bearth (1957a) into a lower element to be correlated with the Monte Leone nappe of the Lepontine Alps and an upper, new Ruginenta nappe (Fig. 3). Bearth (1957a), Laduron and Merlin (1974), Laduron (1976) and Milnes et al. (1981) investigated the former Camughera and Moncucco units. The Monte Leone nappe is characterised by garnet-twomica-plagioclase gneiss intruded by the porphyritic, two micas Moncucco granite dated by the $\mathrm{Rb}-\mathrm{Sr}$ whole rock method at $271 \pm 4.8 \mathrm{Ma}$ (Bigioggero et al. 1981). This unit, exposed in the core of the Vanzone fold, is considered as the southern continuation of the Monte Leone
Fig. 3 Tectonic map of the Monte Rosa region, after Wetzel (1972), Laduron (1976), Steck (1990), Steck et al. (1999, 2001) and Keller et al. (2005), completed with unpublished maps of Master degree geologists from the University of Lausanne and personal observations. Black lines correspond to lithological boundaries that may be stratigraphic, intrusive or tectonic. Complements to the legend: 20 Antrona metabasites, 20a calcschist and marble, $20 \mathrm{~b}$ serpentinite and peridotite, $20 \mathrm{c}$ gabbros, 21 Zermatt-Saas Fee metabasites, 21a sediments, $21 b$ serpentinites. Granite gneiss of the Siviez-Mischabel, Camughera and Ruginenta units are distinguished by contrasted darker colours

nappe (Milnes in Steck et al. 1979). A $50 \mathrm{~m}$ large fold hinge, cored by siliceous marbles, separates at Alpe Pradurino the paragneiss of the Monte Leone nappe from the paragneiss, the Moncucco peridotite and the upper garnet-two micas-plagioclase schist of the Ruginenta

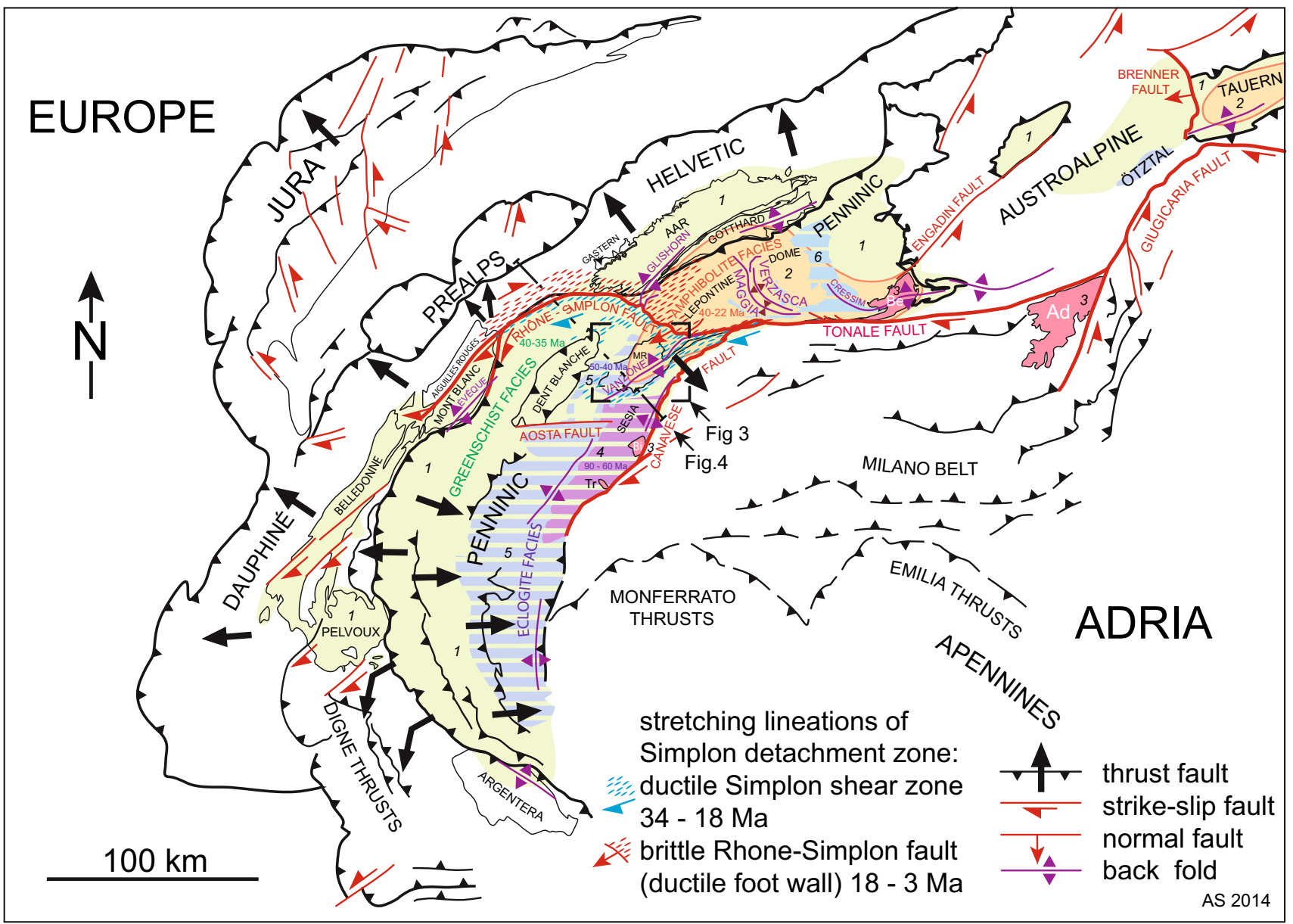

Fig. 2 Late Cretaceous and Tertiary structures and metamorphism of the Central and Western Alps, modified after Frey et al. (1999), Steck et al. $(2001,2013)$ and Oberhänsli (2004) with locations of the structural map of the Monte Rosa region (Fig. 3) and geological Zweisimmen-Monte Rosa section (Fig. 4), 1, (green): Late EoceneMiocene greenschist facies metamorphism, 2, (yellow): Late EoceneOligocene 40-28 Ma amphibolite facies metamorphism, 3, (magenta red): Mantle derived 32-29 Ma (Adamello 42-29 Ma) dioritic magmatism, 4, (violet): Late Cretaceous-Early Paleocene 90-60 Ma eclogite facies metamorphism of the Sesia zone, 5, (blue-violet): Eocene 50-38 Ma eclogite facies metamorphism of the Middle and Upper Penninic nappes, 6, (blue): Late Eocene eclogite facies metamorphism of the Adula nappe 


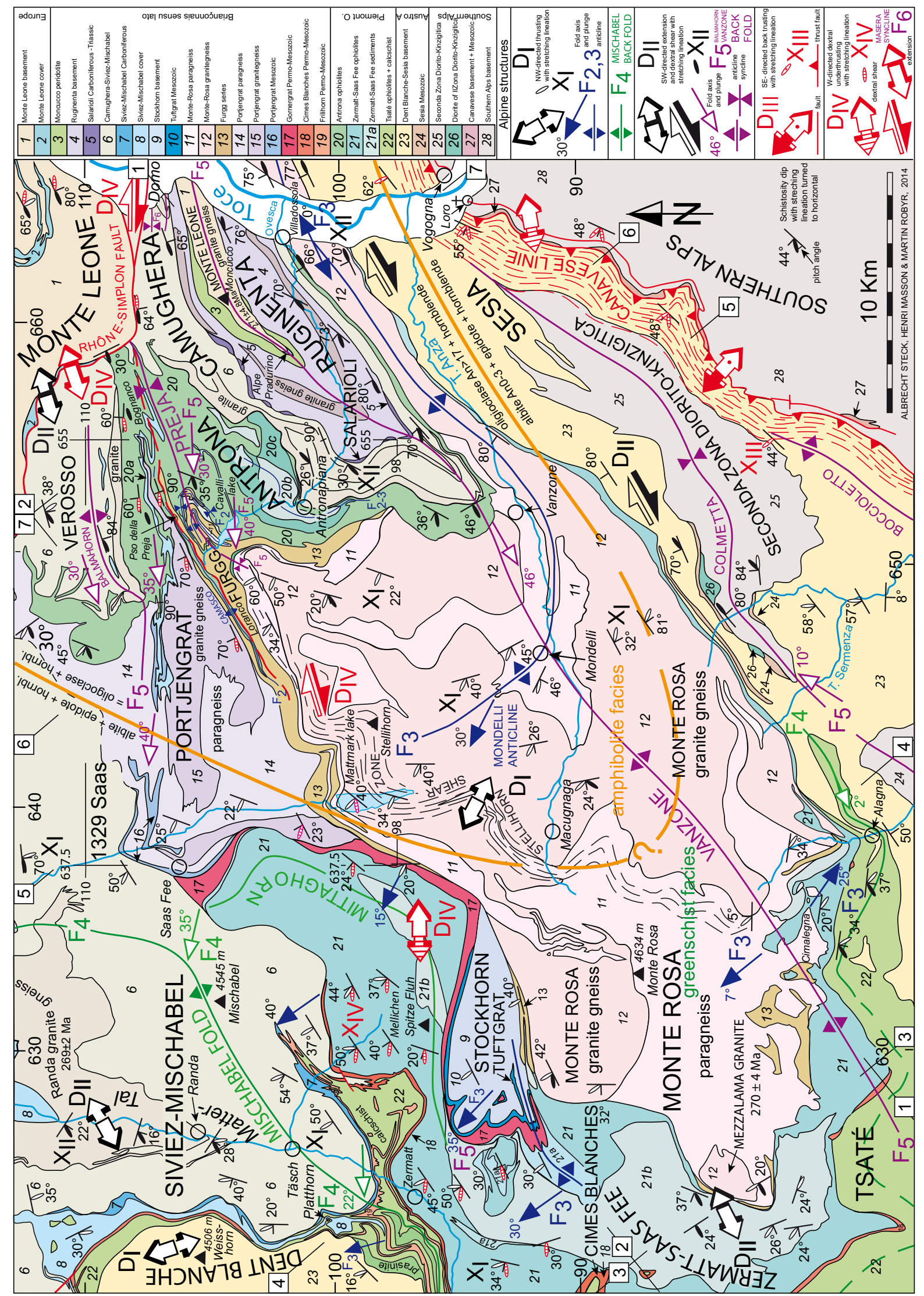




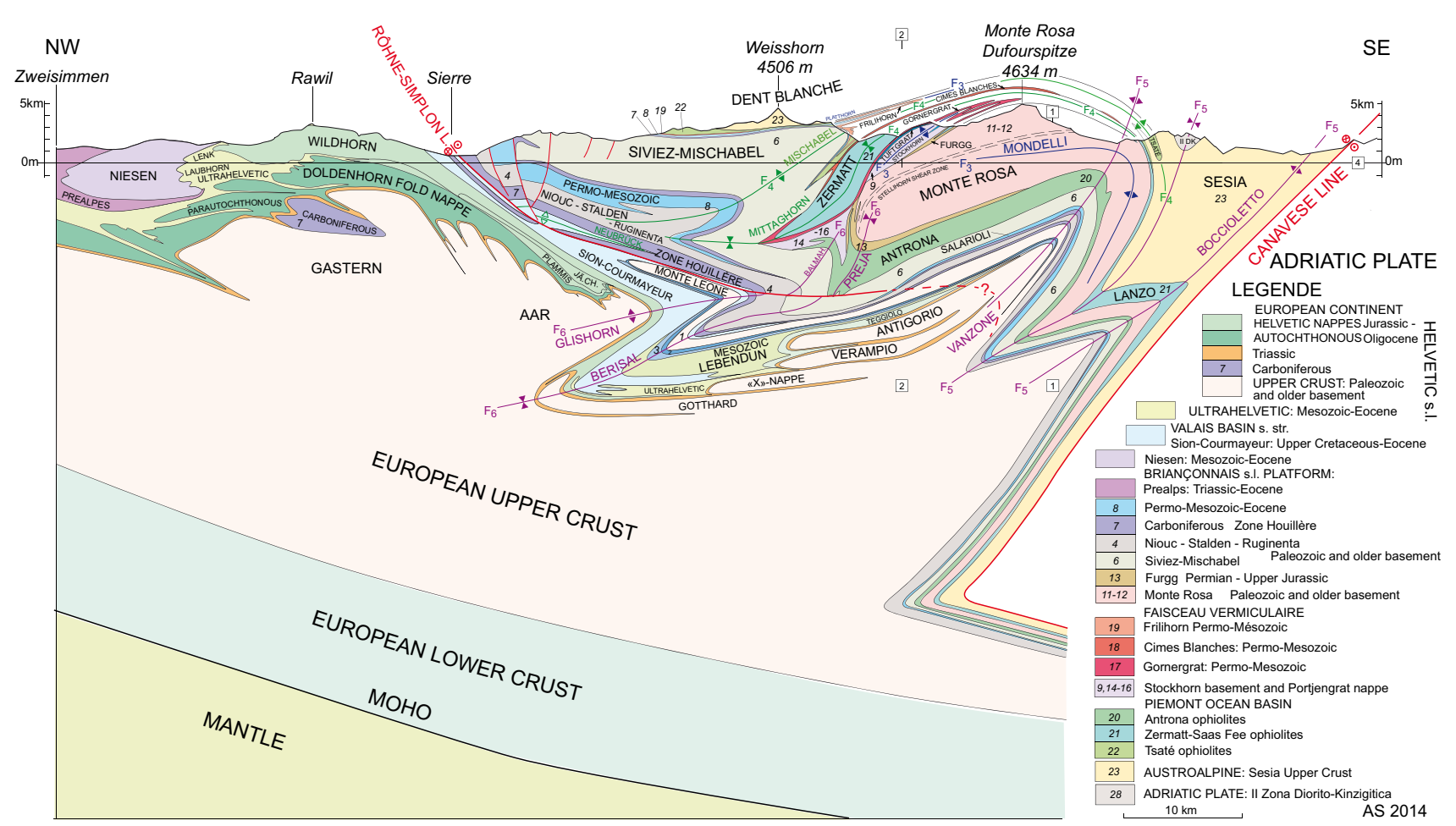

Fig. 4 Schematic geological profile of the Zweisimmen-Rawil-Sierre-Weisshorn-Monte Rosa transect of the Swiss-Italian Alps. The Zweisimmen-Zermatt transect is based on reflexion seismic data of the National Foundation 20 deep seismic project (Escher et al. 1997; Steck et al. 1997). In the frontal part of the Monte Rosa nappe, the axial trace of the Mondelli fold is in fact a «paleo-axial » trace that does not correspond any more today to the definition of an axial trace. This line marks the emplacement where the axial trace was after the

nappe (Fig. 3). The siliceous marbles may represent a remnant of a Mesozoic sequence separating two Alpine basement nappes. Carrupt (2003) described the less deformed stratigraphic column of the Monte Leone nappe front, the Mesozoic (-Tertiary?) Holzerspitz series in the Binn valley. The Monte Leone unit is paleogeographically situated to the north of the Valais basin and classically attributed to the European continent (e.g., Steck et al. 1999, 2001).

\subsection{The Ruginenta nappe}

The newly defined Ruginenta nappe (Steck 2008) consists of pre-Upper-Carboniferous basement stratigraphically overlaid by the Upper Carboniferous and Permo-Triassic sediments of the Salarioli series (Fig. 5). This sedimentary sequence originally described as a synclinal structure, the so-called "Salarioli-Mulde" or Salarioli syncline of Bearth (1957a) represents actually the normal autochthonous stratigraphic cover of the Ruginenta basement. The basement is mainly composed completion of the F3 phase of folding. As curvature is a geometrical property that is not conserved by strain (even homogeneous), this trace has been transformed by younger deformation in such a way that today it is no more a locus of maximum curvature. As for the Berisal fold, the Monte Rosa border was already curved before the F5 phase, so that the point of its intersection with the Berisal axial trace is also not a point of maximum curvature of this borderline. (3) Pizzo del Vallone nappe

of garnet-two micas-plagioclase gneiss or a staurolite and kyanite bearing schist intruded by granite, whereas its lower part consists of the Moncucco peridotite with a thin decametric horizon of garnet-two mica schist at its base. It is not excluded that the Moncucco peridotite represents a distinct nappe, a possible equivalent to the Geisspfad peridotite in the Binn valley (29 on Fig. 1). The Salarioli sedimentary sequence starts with $40 \mathrm{~m}$ of graphite and anthracite bearing, black staurolite-kyanite micaschist, sandstone and conglomerate attributed to the Upper Carboniferous in the Vallone di Trivera near Prabernardo (Antrona valley), reaching $180 \mathrm{~m}$ in the Vanzone fold hinge on the Salarioli pass. The Carboniferous is in the Vallone di Trivera overlaid by about $10 \mathrm{~m}$ of greenish-white, tabular phengite quartzite of Triassic or Permo-Triassic age and $5 \mathrm{~m}$ of Triassic dolomite-limestone marble (Steck 2008). The Ruginenta nappe with its normal sedimentary cover, the Salarioli series, is considered as the southern root of the Berisal zone, the Upper and Lower Stalden zones and the Carboniferous Zone Houillère. 
Table 1 Nomenclature and tentative correlation of Alpine structures observed by various authors in the Monte Rosa region and in the Lepontine gneiss dome

\begin{tabular}{|c|c|c|c|c|c|c|}
\hline & \multicolumn{5}{|c|}{ Correlation of Alpine Structures in the Central Alps } & \multirow[b]{3}{*}{ 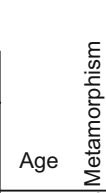 } \\
\hline & & \multicolumn{2}{|c|}{ Monte Rosa region } & \multicolumn{2}{|c|}{ Lepontine dome } & \\
\hline & 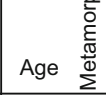 & $\begin{array}{l}\text { Pleuger, Nagel, Jens, } \\
\text { Jansen \& Froitzheim } 2008\end{array}$ & This paper & $\begin{array}{l}\text { Steck 1984, 2008, } \\
\text { Steck et al. } 2013\end{array}$ & \begin{tabular}{|l|} 
Huber, Ramsay \& Simpson \\
1985, \\
Maxelon \& Mancktelow 2005
\end{tabular} & \\
\hline \multirow{5}{*}{ 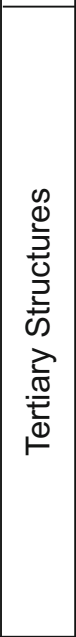 } & \multirow{5}{*}{ 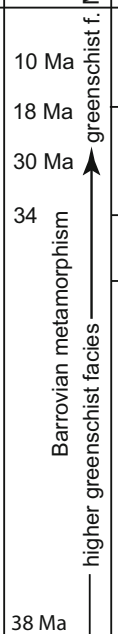 } & & 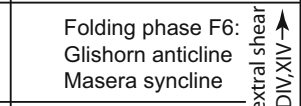 & 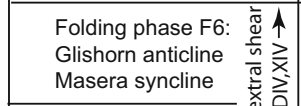 & $\begin{array}{|ll|}\text { Folding phase D4, FA4: } & \stackrel{\Xi}{\Xi} \uparrow \\
\text { Glishorn anticline } & \text { 흥 } \\
\text { Masera syncline } & \text { है }\end{array}$ & \multirow{5}{*}{ 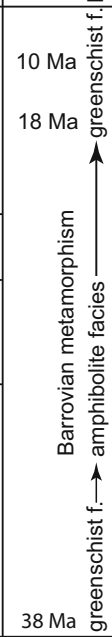 } \\
\hline & & Vanzone phase & 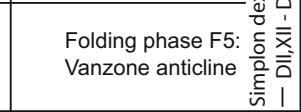 & 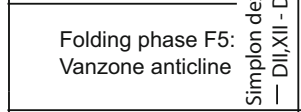 & Southern steep belt, FA4 & \\
\hline & & Mischabel phase & $\begin{array}{l}\text { Folding phase F4: } \\
\text { Mischabel fold } \\
\end{array}$ & no equivalent & no equivalent & \\
\hline & & \multirow[t]{2}{*}{ Malfatta phase } & \multirow{2}{*}{\begin{tabular}{|l|} 
Deformation phase DI \\
with top-to-NW shear XI \\
and SW-verging folds. It \\
comprises three schistosities \\
and folding phases
\end{tabular}} & $\begin{array}{l}\text { Folding phase F4, NW-SE } \\
\text { SW-verging folds: Maggia, } \\
\text { Alpe Bosa, Wandfluhhorn }\end{array}$ & $\begin{array}{l}\text { Folding phase FA3 } \\
\text { with N-S fold axis: } \\
\text { Maggia fold }\end{array}$ & \\
\hline & & & & \begin{tabular}{|c|} 
Deformation phase DI \\
with top-to-NW shear XI. It \\
comprises three schistosities \\
and folding phases \\
schistosity S3, F3 \\
schistosity S2, F2 \\
schistosity S1, F1
\end{tabular} & $\begin{array}{l}\text { Deformation phase D2 } \\
\text { schistosity S2, FA2 } \\
\text { Deformation phase D1 } \\
\text { schistosity S1, FA1 } \\
\text { not described }\end{array}$ & \\
\hline 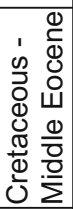 & 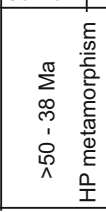 & eclogite & eclogite lineation E-W & $\begin{array}{c}\text { eclogite } \\
\text { Mergoscia and Cimalunga }\end{array}$ & $\begin{array}{c}\text { eclogite } \\
\text { Mergoscia and Cimalunga }\end{array}$ & \\
\hline
\end{tabular}

\subsection{The Camughera-Verosso-Siviez-Mischabel nappe}

The basement gneisses of the Camughera and Verosso units are similar and interpreted as the root of the SiviezMischabel nappe (Argand 1911; Escher et al. 1988, 1993). These three gneissic basements are linked together through the Preja F5 synform and Balmahorn F5 antiform (Fig. 3). Their Variscan and older basement mainly consists of garnet-two micas-plagioclase gneiss and schist containing pre-Alpine migmatite structures, for instance in the Torrente Ovesca bed below Antronapiana. The old basement is intruded by porphyritic, two micas granite gneiss. U-Pb dating of zircon from the Randa granite yields an age of $269 \pm 2 \mathrm{Ma}$ (Bussy et al. 1996). Sartori (1987, 1990), Escher (1988) and Genier et al. (2008) investigated the Carboniferous and Mesozoic cover of the Siviez-Mischabel nappe in the Visp-Zermatt valley ("Matter-Tal", Fig. 3). Sartori (1990) described in the Barrhorn area (Mattertal) the stratigraphic sequence of the sedimentary cover of the Siviez-Mischabel nappe (Figs. 3, 5). It consists of up to $150 \mathrm{~m}$ of Carboniferous greyish quartzite, arkose and graywacke, about $200 \mathrm{~m}$ of Early Permian quartzitic to conglomeratic green or white micaschist, $100 \mathrm{~m}$ of Middle
Triassic dolomitic and calcitic marble, $25 \mathrm{~m}$ of black dolomite and dolomite breccia, $70 \mathrm{~m}$ of Upper Jurassic calcite marble, $25 \mathrm{~m}$ of Upper Cretaceous to lower Eocene phyllitic marble and ends with $15 \mathrm{~m}$ of a black MiddleEocene flysch. This series has a typical Briançonnais sensu stricto affinity (Ellenberger 1953). The autochthonous Carboniferous to Mesozoic stratigraphic sequence of the lower limb of the Siviez-Mischabel nappe outcrops in the Mattertal, south of Visp in an inverse position testifying to the fold nappe geometry of this nappe (Fig. 4; Escher 1988; Genier et al. 2008). A thin band of metasediments of probable Triassic to Cretaceous age is pinched into the gneiss along the southern border of the Verosso element (Cima d'Azoglio; Carrupt and Schlup 1998). Its stratigraphy has an Ultrabriançonnais affinity. It is an open question if this Azoglio series and the adjacent gneiss still belong to the Siviez-Mischabel nappe.

\subsection{The Monte Rosa nappe}

The Monte Rosa nappe consists of an old basement composed of garnet-two micas-plagioclase gneiss and schist and some amphibolite layers, intruded by at least two generations of granites (Bearth 1952, 1953, 1957b). The 


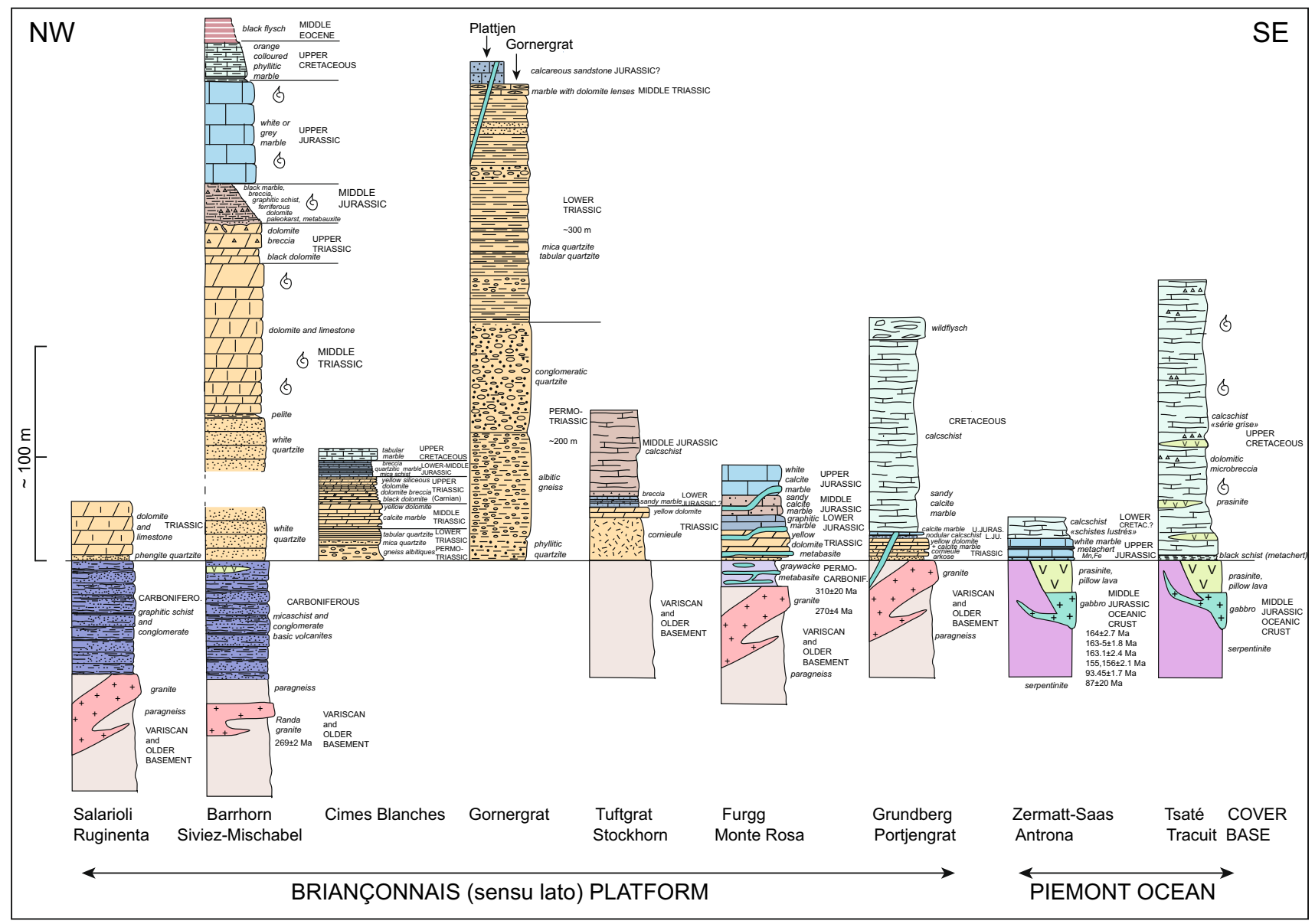

Fig. 5 Stratigraphic columns of the main tectonic units in the Monte Rosa region (modified after Marthaler 1984; Sartori 1987, 1990; Escher 1988; Vannay and Allemann 1990; Carrupt and Schlup 1998;

$\mathrm{Rb}-\mathrm{Sr}$ whole rock age from a sample of the Monte Rosa granite indicate a first phase of granitic intrusion at $310 \pm 20 \mathrm{Ma}$ (Frey et al. 1976). U-Pb zircon geochronology from the porphyritic Mezzalama granite yields younger ages of $270 \pm 4 \mathrm{Ma}$ (Pawlig and Baumgartner 2001). Engi et al. (2001) suggest an U-Pb monazite age at $330 \mathrm{Ma}$ for the main Monte Rosa granodiorite mass. Bearth (1952, 1957b) distinguished the about $25 \mathrm{~km}$ long and up to $2 \mathrm{~km}$ vide Alpine shear zone, the so-called "Stelli zone", named after the Stellihorn peak in the northern part of the Monte Rosa gneisses. It represents an Alpine mylonitised zone of ortho- and paragneisses with amphibolite boudins and rare kyanite and chloritoid bearing white schist. It is named according to Pleuger et al. (2008) the Stellihorn shear zone on the geological and structural maps (Fig. 3). It occupies the northern border of the Monte Rosa nappe between the Loranco valley, the Stellihorn and Mattmark, where it continues in a southern direction to the west of the Monte Moro pass and Macugnaga. Wetzel (1972) proposed a continuation of the Furgg series into Bearth's Stelli zone. We are not
Steck et al. 1999, 2001; Sartori et al. 2006; Steck 2008) and master students works of the University of Lausanne

convinced by this proposition. The gneisses with some amphibolite boudins are attributed to the old Monte Rosa basement. Wetzel and Bearth suggest that the Stelli mylonite zone separates a higher Monte Rosa from a lower Macugnaga sub-unit of the Monte Rosa nappe. Highpressure mineral assemblages of phengite, talc, chloritoid and kyanite in undeformed rocks and in white schist have been interpreted by Pawlig and Baumgartner (2001) as products of the Eocene high-pressure metamorphism overprinting former aluminium rich pre-Alpine metasomatically transformed granite. The interpretation by Bearth (1952) of this aluminium-rich white schist as the product of intense Alpine deformation has therefore to be revised.

\subsection{The Furgg series, composed of the Permo- Carboniferous Cavalli and Mesozoic Preja formations}

Argand (1911) defined the Furgg syncline or Furgg zone as the whole sequence of ophiolites and sedimentary rocks that separates the Monte Rosa basement nappe from the 
Portjengrat basement nappe in the Furgg and Loranco valleys. This Furgg zone continues to the west through the Mattmark area and separates at the Stockknubel, near the Gornergrat, the basement gneisses of the Stockhorn from the Monte Rosa unit (Fig. 10; Bearth 1953). The exact definition and significance of the Furgg zone are still a source of debate (Bearth 1952; Wetzel 1972; Jaboyedoff et al. 1996; Dal Piaz 2001; Keller and Schmid 2001). The whole Furgg zone is strongly affected by Alpine shearing and folding. The Furgg zone does not represent a "tectonic mélange" as previously discussed by Froitzheim (2001) or Pleuger et al. (2005). New observations in the Loranco valley and at the Passo Della Preja allow the distinction between isoclinal folds and slices of Antrona amphibolite, serpentinite and calcschist from the Furgg series, which is a sequence of Upper Paleozoic to Upper Jurassic sediments, crosscut by basic dikes. We call them the Upper Paleozoic Cavalli and Mesozoic Preja Formations of the Furgg series (Figs. 6, 7, 8, 9).

The Zermatt-Saas Fee ophiolites form at the Stockknubel to the east of the Gornergrat an isoclinal slice or fold in the Upper Paleozoic graywackes of the Furgg series (Fig. 10). Centimetre to decametre bands of marbles of the Preja Formation follow the strongly sheared contact between the Upper Paleozoic Cavalli Formation and the Monte Rosa basement in the Furgg and Mattmark valley sections. Two branches of the Furgg zone separated by a Monte Rosa paragneiss zone are exposed at the Mattmark lake dam (Fig. 3). Wetzel (1972) postulates that the eastern branch of the Furgg zone separates the Monte Rosa nappe at the Seewjinerberg in a higher Monte Rosa and a lower Macugnaga complex. This zone corresponds on the 1:25,000 map "Monte Moro" of Bearth (1954b) to a zone of albite-muscovite schist, strongly affected by the Stelli mylonite zone, which is herein attributed to the Monte Rosa basement. Wetzel's (1972) attribution of this zone of paragneiss to the Furgg series is questionable (Steck et al. 1999, 2001).

A complete section through the sedimentary sequence of the Furgg series is exposed at the Passo della Preja (Fig. 6; Steck et al. 2001). The layers of meta-graywacke, metaarkose, mica quartzite and micaschist with numerous amphibolite boudins, of the Cavalli Formation show a tectonic contact with the Antrona ophiolite. These meta-graywackes are overlain by $20 \mathrm{~cm}$ of Triassic quartzite and about $3 \mathrm{~m}$ of dolomite and cornieule, followed by $4 \mathrm{~m}$ of a graphitic sandy calcite marble, $6 \mathrm{~m}$ of a brown weathering siliceous marble and $15 \mathrm{~m}$ of a white calcite marble attributed respectively to the Lower, Middle and Upper Jurassic of the Preja sedimentary Formation. The whole sequence is cross cut by up to $40 \mathrm{~cm}$ thick amphibolite dikes that are strongly affected by boudinage (Jaboyedoff et al. 1996; Figs. 6, 7, 8, 9). The attribution of the different members of the sedimentary sequence is based on lithostratigraphic analogies and a precise dating is difficult due to the lack of fossils. The interpretation of the meta-graywacke with its

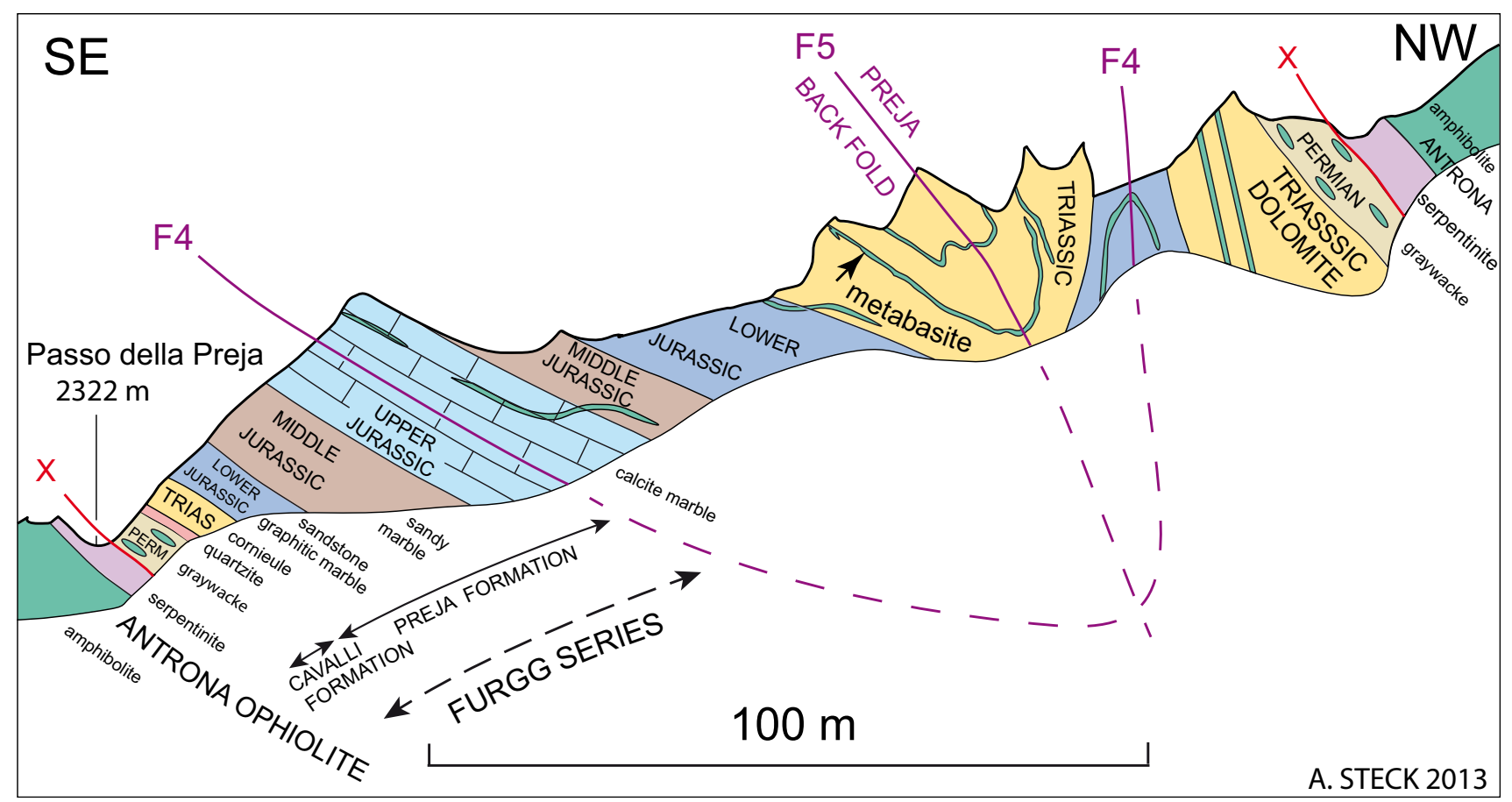

Fig. 6 Geological cross-sections of the Furgg Series composed of the Cavalli and Preja Formations at the Passo della Preja, forming a F4-F5 fold interference structure (Swiss map coordinates: $652.15 \mathrm{~km} / 106.45 \mathrm{~km} /$ altitude $2322 \mathrm{~m}$ ) 


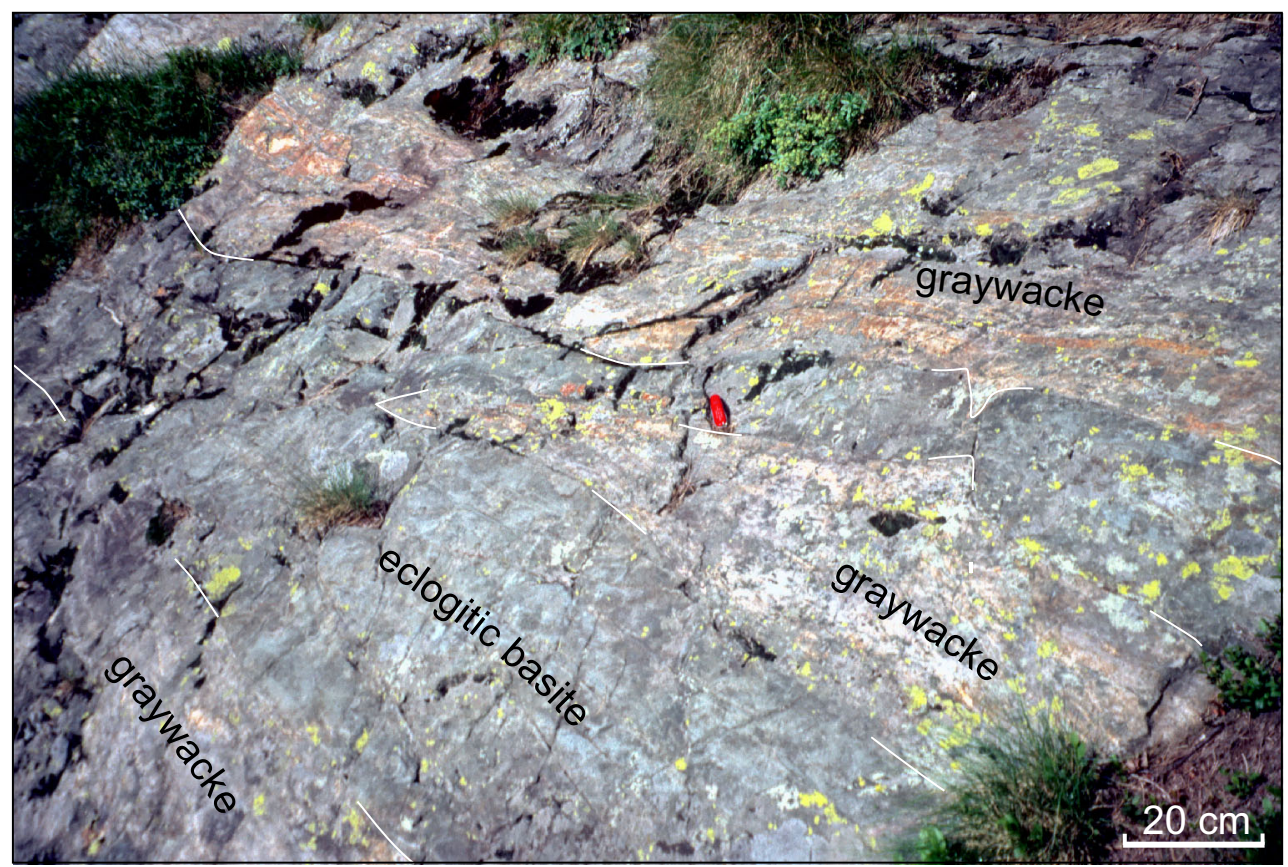

Fig. 7 Branching eclogitic basic dikes in Permian graywacke of the Cavalli Formation, west of lake Cavalli (Swiss map coordinates: $650.65 \mathrm{~km} / 104.15 \mathrm{~km} /$ altitude $1860 \mathrm{~m}$ ). The branching sill crosscuts the stratigraphic layering when jumping to a higher stratigraphic level. Boudinage of the crosscutting basic dike reveals of weak Alpine deformation

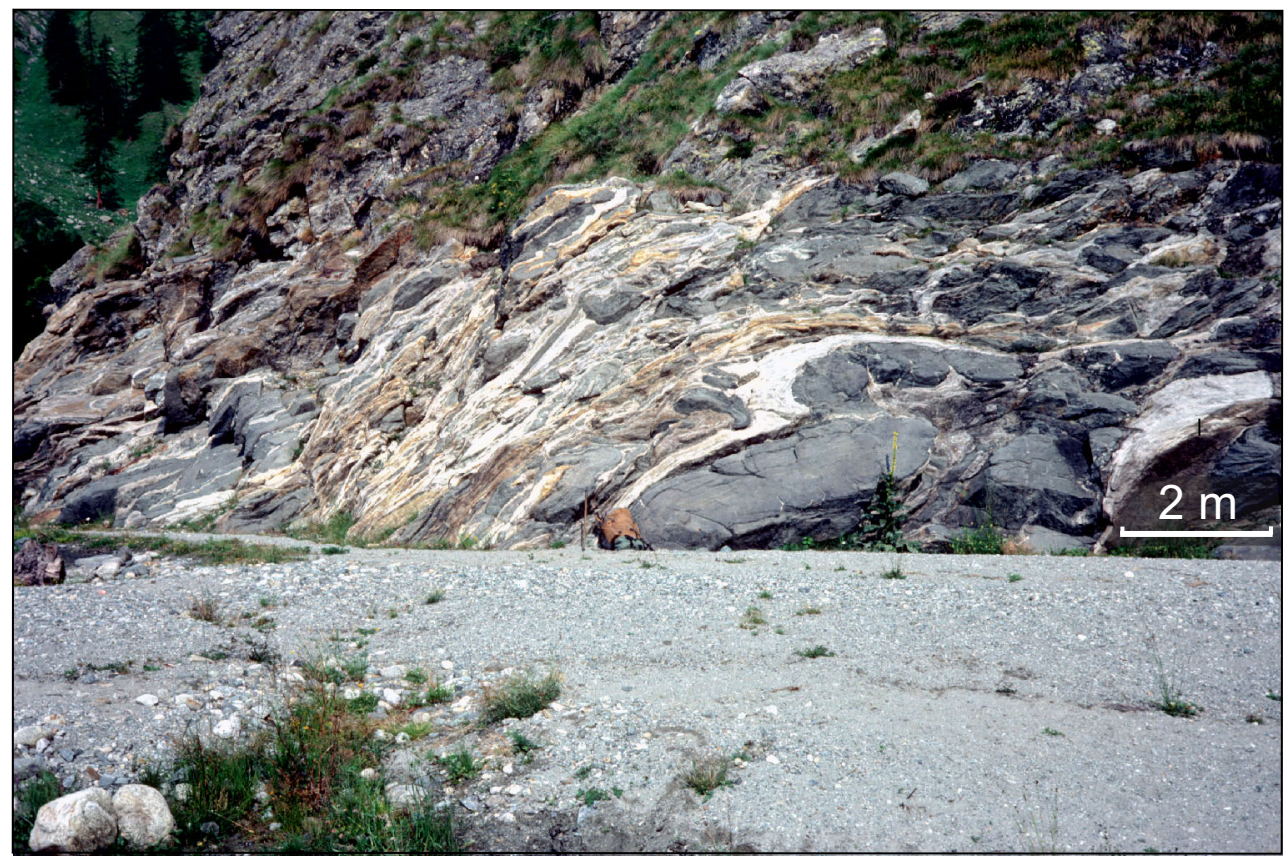

Fig. 8 Outcrop of the Furgg Series at the northern end of lake Cavalli (Swiss map coordinates: $651.15 \mathrm{~km} / 104.85 \mathrm{~km} / \mathrm{altitude} 1490 \mathrm{~m}$ ). Typical boudinage and fold structures of eclogitic basic dikes in Permian meta-arkose and -graywacke of the Cavalli Formation

mafic boudins as sedimentary mélange of Middle Jurassic age discussed by Jaboyedoff et al. (1996) is improbable. All boudins are uniformly amphibolite (retroeclogite) imbedded in a siliciclastic greywacke matrix. No other types of inclusions exist, which would indicate the erosion of an ophiolitic oceanic or continental crust. The Upper Paleozoic age, probably Permian, proposed by Bearth (1952) and Wetzel (1972) for the herein defined Cavalli 


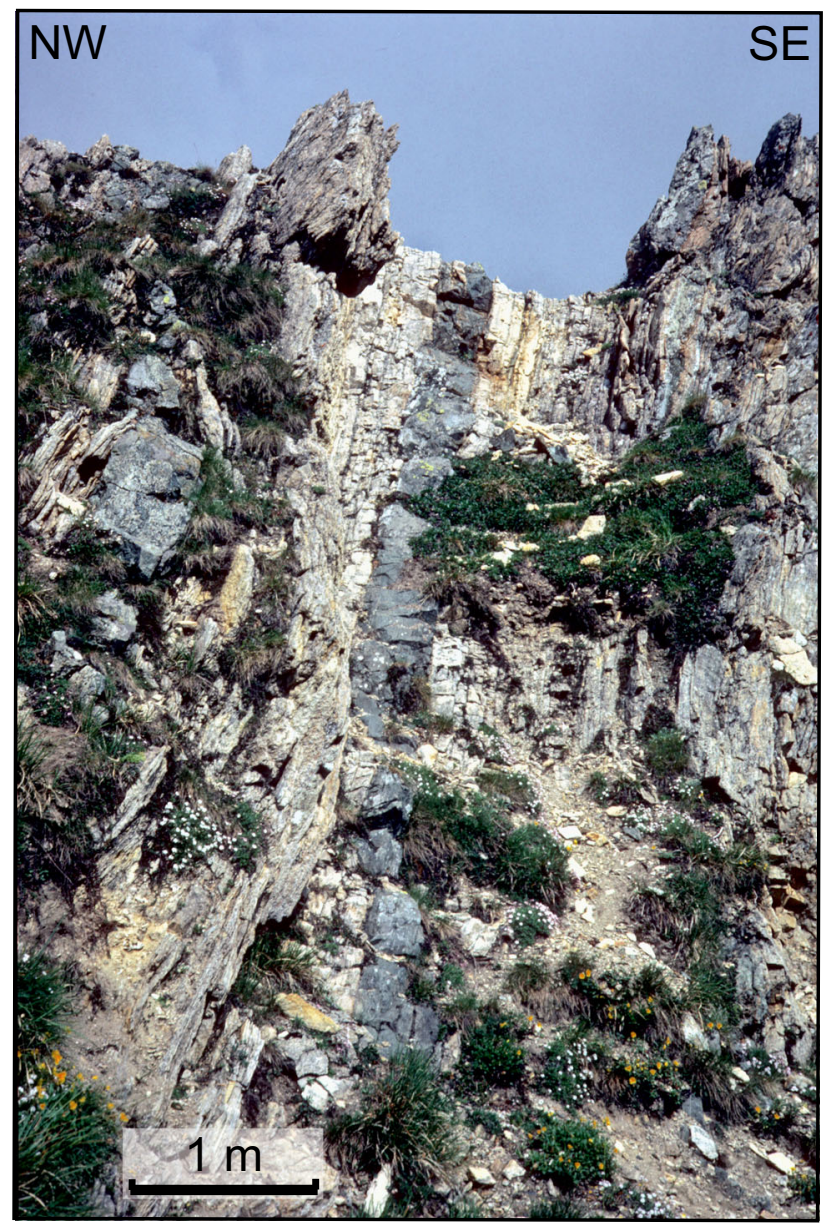

Fig. 9 Triassic dolomite of the Preja Formation cross-cut by about $30 \mathrm{~cm}$ thick basic dikes in the ridge $150 \mathrm{~m} \mathrm{NW}$ of the Passo della Preja (Swiss map coordinates: $652.06 \mathrm{~km} / 106.52 \mathrm{~km} / \mathrm{altitude}$ 2370 m; Fig. 5 in Jaboyedoff et al. 1996)

Formation is more plausible (Steck et al. 2001). This age is also supported by an $\mathrm{Rb}-\mathrm{Sr}$ whole rock isochron of $275 \pm 20 \mathrm{Ma}$ (Frey et al. 1976). The graywackes of the Cavalli Formation overlie the old Monte Rosa basement and Permo-Carboniferous granites on Alpine deformed contacts. Wetzel (1972) suggests an autochthonous basement-cover relation. The amphibolitic dykes are late-or post-Jurassic. Figures 7 and 8 illustrate how the Upper Paleozoic Cavalli Formation typically looks like near the Cavalli Lake. Figure 7 shows only little deformed branching basic dikes cross cutting the stratigraphic layering of the Paleozoic greywacke. The outcrop on the northern end of the Cavalli Lake (Fig. 8) illustrates the widespread strong Alpine deformation by folding and boudinage. The Upper Paleozoic sediments of the Furgg series with their amphibolite boudins show near the Andolla refuge in the Loranco valley a sharp contact with the Paragneiss of the Portjengrat unit, which was interpreted by Keller and Schmid (2001) as an autochthonous cover- basement relationship. The Alpine deformation is in this region very intense and no sedimentary structures, characteristic of an autochthonous sedimentary contact are observable. The significant difference in lithology between the Furgg series in the Loranco valley and Passo della Preja and the autochthonous Mesozoic series on the Portjengrat basement at the Grundberg in the Saas valley (Fig. 5) gives evidence that both series have a distinct paleogeographic origin. Lenses of the Cavalli Formation are exposed all along the outer contact and also inside the Monte Rosa nappe (Wetzel 1972; Dal Piaz 2001). A thin band of micaschist with amphibolite boudins, attributed to the Cavalli Formation is intercalated between the Monte Rosa gneiss and the Antrona ophiolites in the Ovesca riverbed at Villadossola. It is suggested that the Furgg sedimentary series has been overthrust to the north from an original paleogeographic position situated on the southern part of the Monte Rosa basement.

\subsection{The Portjengrat nappe}

The basement gneisses of the Portjengrat nappe are similar to those of the Monte Rosa, Siviez-Mischabel, Camughera and Ruginenta nappes. Bearth (1939) discussed the complex and still controversial relationship of the Portjengrat unit with the Monte Rosa and Siviez-Mischabel nappes. Masson (2002) proposed that it belongs to neither of their units but it forms an independent small continental block, originally stuck in paleogeography between the Antrona and Zermatt-Saas Fee branches of the Piemont Ocean. The Monte Rosa and Portjengrat units differ through their Alpine high-pressure mineral assemblages (3T phengite polytype) from the greenschist to amphibolite facies Siviez-Mischabel basement gneiss with its $2 \mathrm{M}$-phengite polytype (Frey et al. 1983; Vincent Baudraz, personal communication). The boundary between the two units is uncertain. It may be situated in a zone of mylonite that crosses the western ridge of the Weissmies (Huang 1936). The basement of the Portjengrat nappe is overlain at the Grundberg above Saas-Grund by its autochthonous Mesozoic sedimentary sequence studied by Vincent Baudraz (personal communication). The Grundberg series starts with a Triassic sequence composed by up to $2 \mathrm{~m}$ of basal arkose, $2 \mathrm{~m}$ of dolomitic marble and cornieule (rauhwacke). $50 \mathrm{~cm}$ of a nodular calcschist and $1 \mathrm{~m}$ of a pure calcite marble, attributed to the Jurassic, separate the Triassic sequence from the probable Late Cretaceous sequence composed by $80 \mathrm{~m}$ of calcschist and $9 \mathrm{~m}$ of a sedimentary mélange (wildflysch; Fig. 5). Basaltic dikes occur in both the gneissic basement and the sedimentary cover (marbles) of the Portjengrat unit in the Val Bognanco (Carrupt and Schlup 1998). 


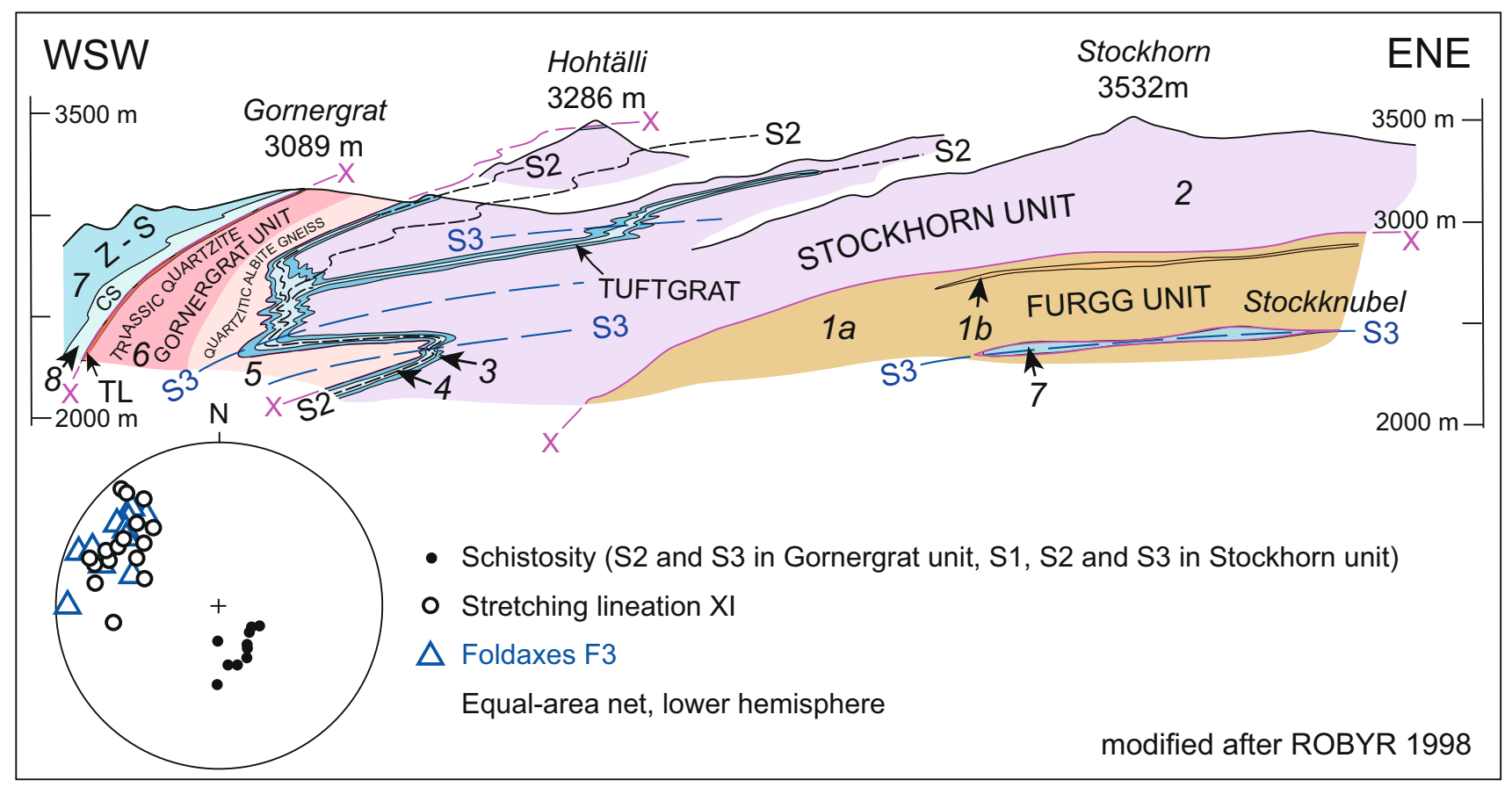

Fig. 10 Geological section through the Gornergrat and Stockhorn (after personal communication by Martin Robyr 1988), other structural data are represented on stereogram 3 of Fig. 16. 1a Furgg Permo-Carboniferous graywacke with basic boudins (Cavalli F.), $1 b$ Furgg Mesozoic marble (Preja F.), 2 Stockhorn paragneiss, 3 Tuftgrat

\subsection{The Stockhorn nappe}

The Stockhorn nappe consists of Paleozoic basement schist or gneiss composed of meta-pelite, meta-arkose and metagraywacke overlain by the Mesozoic Tuftgrat sedimentary series (Figs. 5, 10). The basement schist contains a greenschist facies assemblage of white mica, garnet, quartz, chlorite, and \pm chloritoid, \pm albite. The Tuftgrat series starts with cornieule (rauhwacke). These Triassic sediments are overlain by $\sim 10 \mathrm{~m}$ of sandy marble with phyllitic intercalations, a few meters of calcibreccia of probable Jurassic age and over $20 \mathrm{~m}$ of dark brown calcschist of unknown age. Bearth (1953), Escher (1988) and Escher et al. (1988) describe the Stockhorn unit and the higher Gornergrat nappe envelope as a SW-verging fold of the Monte Rosa nappe. But the study of the Stockknubel region suggests that the Stockhorn nappe is separated from the Monte Rosa basement by the Furgg zone (Figs. 3, 10).

\subsection{The Gornergrat nappe}

The Gornergrat nappe is exposed at the type locality and below the Mittaghorn in the Saas valley, as a $300 \mathrm{~m}$ thick band bounded along its top by the Zermatt-Saas Fee ophiolites and along its base by the Portjengrat gneiss (Figs. 3, 5). A $10 \mathrm{~m}$ thick layer of garnet-muscovite schist
Triassic dolomite, 4 Tuftgrat Jurassic marble, 5 Gornergrat PermoTriassic quartzitic albite gneiss, 6 Gornergrat Triassic quartzite and limestone (TL), 7 Zermatt-Saas Fee ophiolite, 8 Zermatt-Saas Fee calcschist (CS)

intercalated in the calcschist at the base of the ZermattSaas Fee ophiolites is tentatively attributed to the Gornergrat nappe. Two generations of garnet support the poly-metamorphic history of this garnet-muscovite schist (Caroline de Meyer personal communication). Caroline de Meyer interprets the garnet-muscovite schist layer as an isoclinal fold or tectonic slice of the Gornergrat nappe. The Gornergrat nappe is characterized by a normal stratigraphic sequence. A $330 \mathrm{~m}$ thick quartzitic and conglomeratic albite-white-mica schist and tabular whitemica quartzite sequence is attributed to the Permo-Triassic that has a definite Briançonnais affinity. This sequence is overlain by $10 \mathrm{~m}$ of limestone and thinner boudinaged layers of dolomite, that also show a strong lithological affinity with the Middle Triassic carbonates of the Briançonnais domain. They are followed by a few tens of metres of calcareous sandstones. All these rocks are crosscut at Swissmap coordinates $639,192 / 103821$ by mafic dikes (Fig. 5, south of Plattjen), where Caroline de Meyer (personal communication) observed albite-hornblende symplectites which probably testify of retrograde greenschist facies recrystallization of former omphacite. Also the high Si content of the phengite corroborates an early high-pressure metamorphism of the Gornergrat nappe. The crystallisation of tremolite in the siliceous dolomite marbles indicates conditions at the limit of 
greenschist and amphibolite facies of the younger Barrovian metamorphic overprint.

\subsection{The Cimes Blanches nappe}

Argand (1916) distinguished the Cimes Blanches and Frilihorn nappes as the "Faisceau vermiculaire". The Cimes Blanches and Frilihorn nappes comprise the same stratigraphic sequence as the Gornergrat nappe but occur in a different tectonic position (Figs. 3, 4, 5, 11). Vannay and Allemann (1990) studied the stratigraphic series of the Cimes Blanches nappe at the Cimes Blanches type locality (Figs. 3, 5). They propose a lithostratigraphic correlation with the well-known and paleontologically dated members of the Barrhorn series of the Siviez-Mischabel nappe (Sartori 1987, 1990; Fig. 5). The series is composed from base to top of over $5 \mathrm{~m}$ of a Permo-Triassic albite gneiss, $\sim 2 \mathrm{~m}$ of mica quartzite and $\sim 3 \mathrm{~m}$ of tabular quartzite attributed to the Lower Triassic, over $10 \mathrm{~m}$ of an alternation of yellow dolomite and grey calcite marble of the Middle Triassic, over $10 \mathrm{~m}$ of Upper Triassic black dolomite, dolomite breccia ending with yellow siliceous dolomite, over $6 \mathrm{~m}$ of an alternation of albite micaschist, nodular and siliceous marble and breccia attributed to the Lower Jurassic and over $4 \mathrm{~m}$ of Upper Cretaceous (?) yellow siliceous calcite marble.

\subsection{The Frilihorn nappe}

The Frilihorn nappe (Marthaler 1984) presents a stratigraphic sequence similar to the Cimes Blanches nappe. It is separated from the Cimes Blanches nappe and intercalated in the calcschist of the ophiolitic Tsaté nappe (Figs. 3, 4, 11).

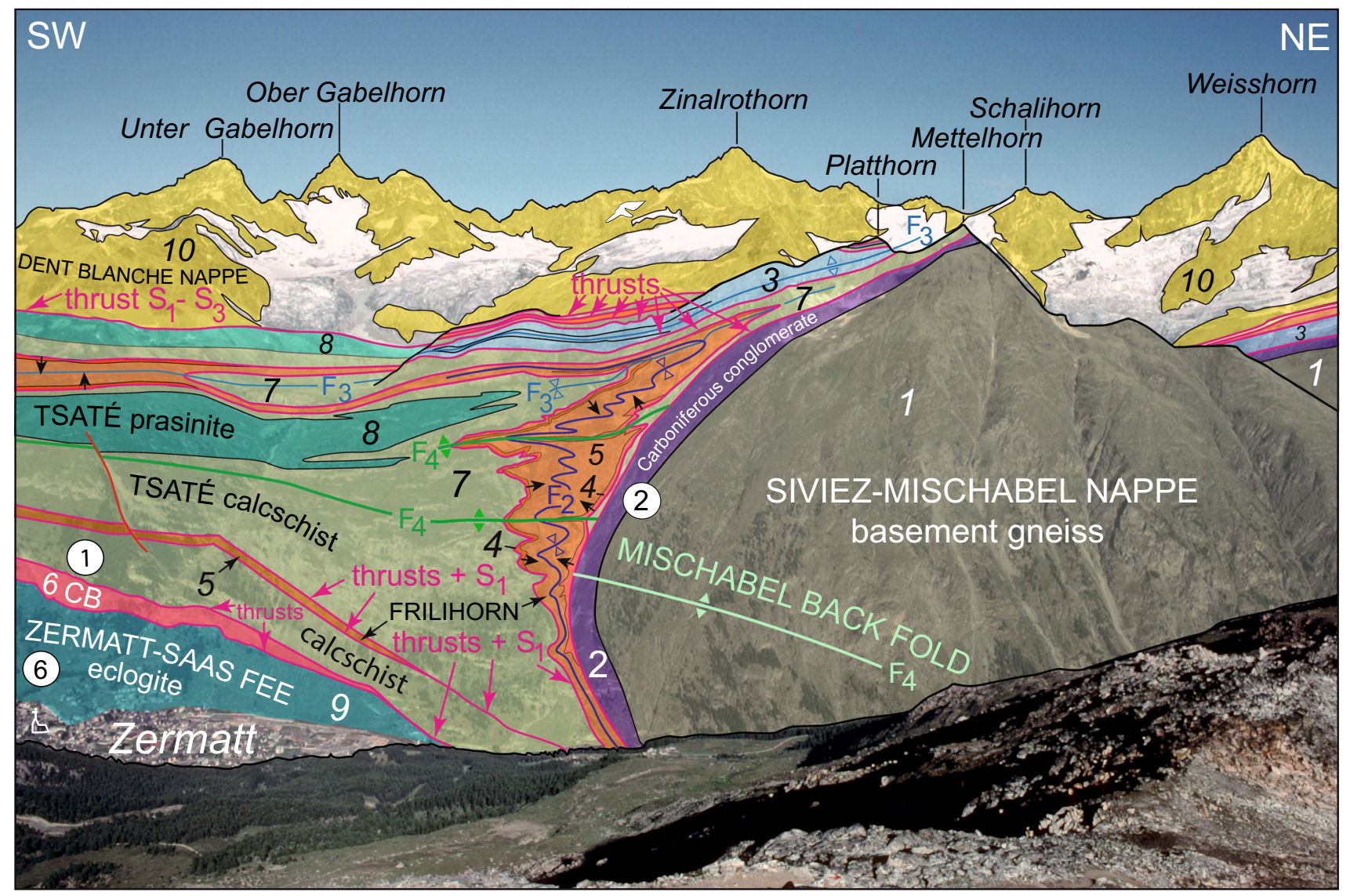

Fig. 11 Structures of the Mischabel backfold, view from Sunnegga above Zermatt. Geological structures modified after Sartori (1987, 1990), Sartori et al. 2006, Steck (1989) and Steck et al. (1999, 2001). 1 Basement gneiss of the Siviez-Mischabel nappe, 2, 3 its sedimentary cover, 2 Carboniferous conglomerates, 3 Barrhorn MesozoicEocene series, 4, 5 Frilihorn Mesozoic series, 4 Frilihorn quartzite, 5 Frilihorn dolomite, $\uparrow=$ younging upwards stratigraphic polarity, 6 CB Cimes Blanches nappe (Permo-Mesozoic series), 7 calcschist of the ophiolitic Tsaté nappe, 8 prasinite, meta-basite of the Tsaté nappe,
9 eclogitic Zermatt-Saas Fee ophiolitic nappe, 10 Dent Blanche basement nappe. Red lines are multiple folded thrust planes, F2 = axial surface of second-phase folds, F3 = axial surface of third-phase folds, F2 and F3 fold axes are oriented parallel to a NWdirected stretching lineation with top-to-NW shear indicators, $\mathrm{F} 4=$ axial surfaces of Mischabel back fold with its $22^{\circ} \mathrm{W}$-plunging fold axis (stereogram (2) on Fig. 16), (1) stereogramm Alterhaupt and (6) Zermatt-Saas Fee on Fig. 17 


\subsection{The Antrona and Zermatt-Saas Fee ophiolite nappes}

The map reveals the superposition of isoclinal folds and large tectonic slices in the internal structure of the Alpine deformed Antrona and Zermatt-Saas Fee unites. These ophiolitic units are composed of serpentinite, eclogite, amphibolite, prasinite, meta-gabbro, marble, chert (metaradiolarite), garnet-micaschist and calcschist. The serpentinites preserve in the Antronapiana region, at Alpi di Cama, Pt. 1827 m, a large relictic body of peridotite. The serpentinites are mainly composed of antigorite, with a rim of talc, chrysotile, actinolite, chlorite and magnetite ("pierre ollaire") at the contact with the amphibolite or prasinite. Intrusive mafic dikes in the serpentinites are transformed into rodingite, composed of epidote, vesuvianite, actinolite, diopside and grossular. Pillow lava structures are observed in the amphibolite and eclogite (Bearth 1967). Calcite marbles of probable Upper Jurassic age that contain detrital graded bedding structures overlie serpentinite or amphibolite with primary sedimentary contacts. This feature testifies to the complexity of the Middle and Late Jurassic extensional structures of the Piemont oceanic floor. Piemontite quartzite schist and black chert are also observed (Fig. 5). The calcschist with detrital ophiolite elements is likely Cretaceous. U-Pb SHRIMP dating on zircon yields in the Zermatt-Saas Fee nappe an age at $164 \pm 2.7 \mathrm{Ma}$ for the Allalin gabbro and an age at $163-5 \pm 1.8 \mathrm{Ma}$ for the Mellichen gabbro (Rubatto et al. 1998). The same method gives for the Antrona ophiolites in the Loranca valley ages ranging from $163.1 \pm 2.4 \mathrm{Ma}$ to 155 and $156 \pm 2.1 \mathrm{Ma}$ (Liati et al. 2005) testifying to the Middle Jurassic age of the Piemont oceanic floor. An U-Pb SHRIMP age on zircon of $93.4 \pm$ 1.7 Ma (Cenomanian; Liati and Froitzheim 2006) was obtained in an eclogite of the Balma unit exposed in the upstream part of the Valsesia, north of Alagna (Pleuger et al. 2005). This age is compatible with an U-Pb SHRIMP age on zircon of $87 \pm 20 \mathrm{Ma}$ (Late Cretaceous) in an amphibolitic eclogite from Andolla in the Loranco valley (Liati et al. 2001). The post-Late Jurassic basaltic intrusions in the Furgg and Portjengrat series provide an additional argument supporting magmatism during Cretaceous. It is premature to say if these Cretaceous ages represent a separate magmatic pulse or the end of an on-going magmatic activity from Middle Jurassic to Late Cretaceous.

\subsection{The Tsaté ophiolite nappe}

The term "Combin zone" has been often used since Bearth (1953) in the Alpine literature for this unit. However Argand $(1909,1911)$ had defined the "Combin zone" as the entire composite set of Mesozoic metasediments and ophiolites that separate the Gd. Saint Bernard basement (here Siviez-Mischabel basement) from the Dent Blanche basement, well aware that it comprised several distinct tectonic units. The Tsaté nappe is only one of these units. Although it is the thicker one, it is recommended to maintain Argand's original definition of the Combin zone (Trümpy 1980) and to apply the name Tsaté nappe, introduced by Sartori (1987) and Escher et al. (1988), to the part of it made of ophiolite-bearing calcschist ("schistes lustrés").

The composition of the Tsate nappe is similar to the Zermatt-Saas Fee and Antrona nappes, however with a larger proportion of metasediments. Its internal structure is complex. It is dismembered into numerous thrust-sheets and tectonic slivers that are interpreted as a former accretionary prism formed during subduction along an active margin (Marthaler and Stampfli 1989; Steck 1989). The theoretical original stratigraphic column would consist of an oceanic floor (ophiolite) overlain by oceanic sediments (Fig. 5; Marthaler et al. 2008). The ophiolites are represented by serpentinites, metagabbros and metabasalts with pillow lava structures. They have never been dated and are ascribed to Middle to Late Jurassic by analogy with the gabbros of the Zermatt-Saas Fee nappe (see above) and of the Gets nappe in the Prealps (Bill et al. 1997). The metasediments consist of marble and chert ascribed to the Late Jurassic and above all of thick masses of Cretaceous calcschist partly dated by Cenomanian-Turonian foraminifera (Marthaler 1984). Intercalations of metabasites in the calcschist are abundant: it is difficult to discriminate between magmatic recurrences, tectonic slices, blocks (olistolites) or volcanoclastic resediments. The Tsaté nappe differs from the eclogitic Zermatt-Saas Fee and Antrona nappes by its lower pressure and temperature metamorphic assemblages indicating high-pressure greenschist facies conditions (Ballèvre and Merle 1993; Reddy et al. 1999; Negro et al. 2013).

\subsection{The Dent Blanche-Sesia nappe}

The Austroalpine Dent Blanche nappe and its southern root, the Sesia zone (Figs. 1, 3 and 4), consist in the study area of a polycyclic basement gneiss intruded by Palaeozoic gabbros (Mont Collon gabbro: $\mathrm{U} / \mathrm{Pb}$ zircon age of $284.2 \pm 0.6 \mathrm{Ma}$, Monjoie et al. 2007; Anzasca gabbro: 288 $+2 /-4$ Ma, Bussy et al. 1998) and younger crosscutting granites (Mont Collon pegmatitic granite: $\mathrm{U} / \mathrm{Pb}$ zircon age of $282.9 \pm 0.7$, Monjoie et al. 2007). The gabbros at the base of the Dent Blanche thrust are strongly deformed and metamorphosed under greenschist facies conditions. Discriminating these gabbros from the underlying meta-gabbros of the Tracuit zone (Tsaté nappe) can be challenging (Bearth 1953; Sartori 1987; Figs. 3, 11). The metamorphic 
mineral assemblage of quartz, albite, epidote, actinolite, chlorite, titanite, \pm biotite, with some Fe-riebeckite (not Mg-glaucophane) indicates greenschist facies conditions. Some bands of dolomite and calcitic marble in the Sesia gneiss are interpreted as remnants of its Mesozoic sedimentary cover (Venturini 1995). The rocks of the Sesia zone preserve an Alpine metamorphic gradient evolving from greenschist facies conditions in the study area to amphibolite facies of the Barrovian regional metamorphism of the Central Alps toward the NE (Fig. 3). The Sesia zone underwent farther south, (Fig. 2), out of the limits of the geological map (Fig. 3), eclogitic high-pressure metamorphism during Late Cretaceous (90-60 Ma; Dal Piaz et al. 1972; Hunziker et al. 1992; Duchène et al. 1997; Rubatto et al. 1998, 1999; Babist et al. 2007). The "Seconda Zona Diorito-Kinzigitca" klippe and the Southern Alps are not described herein.

\section{Structural and metamorphic evolution}

\subsection{Introduction}

The Middle Penninic nappes consist of Variscan and older polymetamorphic basement gneiss intruded by Late Paleozoic granites and covered by their Mesozoic to Tertiary sedimentary series. The composition of the Grundberg, Tuftgrat, Gornergrat, Cimes Blanches, Barrhorn and Salarioli series and their Paleozoic basements suggests a common Briançonnais (s.l.) continental origin (Escher 1988; Steck et al. 1999, 2001; Sartori et al. 2006). The Upper Paleozoic to Upper Jurassic Furgg sediment cover of the Monte Rosa nappe is to strongly deformed and metamorphosed that it doesn't allow its attribution to a specific paleographic domain. The Upper Penninic Tsaté, ZermattSaas Fee and Antrona units are composed of ophiolites of the Middle Jurassic-Cretaceous Piemont oceanic crust and serpentinites of the denuded mantle with their (Middle? -) Late Jurassic and Cretaceous-Paleocene oceanic floor sediments (partly expelled to the Prealps). Paleogeographic reconstructions by Trümpy (1980), Escher et al. (1997), Stampfli et al. (2001) and Bernoulli et al. (2003) suppose that the Middle Jurassic-Cretaceous Piemont oceanic basin separates the Briançonnais s.l. continental crust to the north (including the Subbriançonnais Stalden-Berisal-Ruginenta, the Briançonnais s. str. Camughera-Siviez-Mischabel and Cimes Blanches, and the Prepiemont Mont Fort, Stockhorn, Monte Rosa and Portjengrat) from the Austroalpine Sesia and Southalpine Adriatic continental blocks to the south (Fig. 12). The complexity of the geometry of the Piemont oceanic basin or basins may account for the present-day cartographic discontinuity between the ZermattSaas Fee and Antrona ophiolitic units.

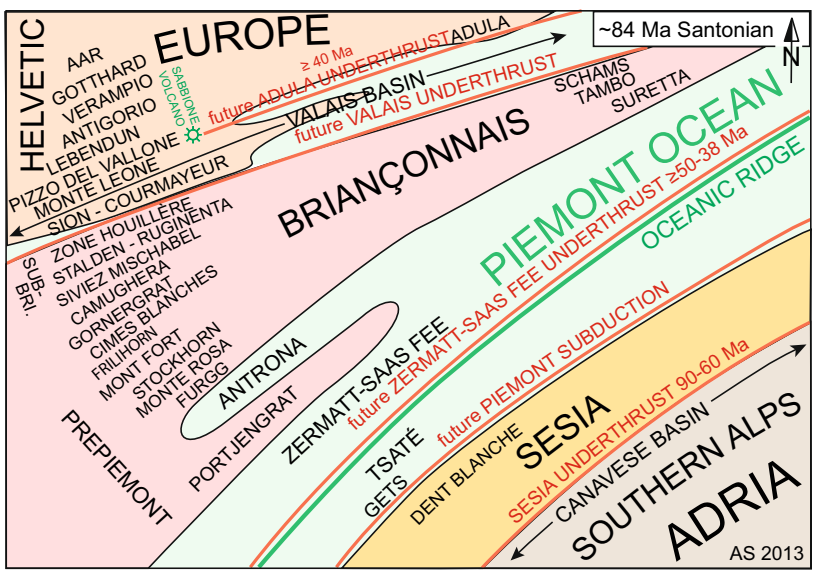

Fig. 12 Tentative paleogeographic interpretation of the Alpine Tethys in the Central Alps before the Tertiary collision of the converging Europe and Adria plates (modified after Steck et al. 2013); the Sabbione volcano of middle Jurassic age (Carrupt 2003) stands at the western continuity of a northern branch (Orselina-Bombogno) of the Valais basin (denuded continental mantle window)

Froitzheim (2001), Pleuger et al. (2005), and Herwartz et al. (2008) proposed a different paleogeographic model. They suggest that the Monte Rosa unit formed the southern margin of the European (Helvetic) crust separated to the south by the Valais basin from the Briançonnais terrain, the latter being separated by the Ligurian basin (Piemont ocean) from the Adria margin. The Antrona ophiolites are attributed to the Valais basin. We agree that the highly deformed and metamorphosed sedimentary cover of the Monte Rosa nappe (Furgg series) is not specific and could be attributed to various paleogeographic positions. But the correlation of the Mesozoic sediments of the Antrona ophiolites with the flyschoid sediments of the Valais basin is very questionable. No equivalents of the Sion-Courmayeur flysch (or contourite) series exist in the Antrona nappe. On the other hand, the Mesozoic series of the Antrona and Zermatt-Saas Fee nappes are quite similar. Froitzheim and collaborators also contest the southern rooting of the Briançonnais Siviez-Mischabel nappe through the Verosso and Camughera gneiss situated below the Antrona nappe as proposed by Argand (1911) and by Milnes in Steck et al. (1979), (Milnes et al. 1981) and in the geological sections of Escher et al. (1988, 1993), (Steck et al. 1999, 2001; Steck 2008; Fig. 4).

The Tertiary Alpine structures result from the collision, the SE-directed subduction, the extrusion and accretion of upper crustal slices detached from the European and Briançonnais plate below the Adriatic plate (e.g., Trümpy 1980; Laubscher and Bernoulli 1982). Figure 12 suggests the paleogeographic situation at the Santonian, some $84 \mathrm{Ma}$ ago, before the Alpine collision of the two converging plates. The proposed regional distribution of the 
different units is tentative. Structural, metamorphic and geochronological constraints enable the temporal distinction of successive phases of underthrusting, extrusion and collision in the Alpine thrust belt during the Adria and Europa plate convergence. Three regional metamorphic events (Figs. 2, 3) are followed by two episodes of magmatic activity. A high-pressure metamorphic event occurred during the Late Cretaceous-Paleocene (90-60 Ma) in the southern Sesia zone (Fig. 2; Hunziker et al. 1992; Duchène et al. 1997; Ruffet et al. 1997; Rubatto et al. 1999; Konrad-Schmolke et al. 2006; Babist et al. 2007). Jan Pleuger (personal communication on the Swiss Tectonic Group excursion March 2014) dates synkinematic crystallised Alpine white mica in Sesia mylonites of the extruding Dent Blanche-Sesia nappe with the ${ }^{40} \mathrm{Ar} /{ }^{39} \mathrm{Ar}$ method at $63.09 \pm 0.77 \mathrm{Ma}$. This age corroborates $\mathrm{K}-\mathrm{Ar}$ ages obtained by Zingg and Hunziker (1990), (Zingg et al. 1990) from the Montalto region. Then the rocks of the Zermatt-Saas Fee, Tsaté, Portjengrat and Monte Rosa units were metamorphosed at high-pressure to ultra-high-pressure conditions during the Eocene (50-38 Ma; Gebauer 1999; Amato et al. 1999; Engi et al. 2001; Lapen et al. 2003; De Meyer et al. 2014). Finally a Late Eocene-Early Miocene (40-18 Ma) Barrovian regional metamorphism occurred in the Central Alps (Hurford 1986; Hunziker et al. 1992; Steck and Hunziker 1994; Markley et al. 1998; Engi et al. 2001, 2004; Rubatto et al. 2009; Janots et al. 2009). Following these three metamorphic episodes, magmatic activity is responsible for the intrusion of Oligocene (32-29 Ma) mantle derived andesitic dikes (including the Traversella, Biella and Bergell intrusions, Figs. 1,2) along the Insubric line and for the 29-25 Ma crustal aplite and pegmatite dikes in the southern steep belt between Domodossola and the Bergell (Beccaluva et al. 1983; Romer et al. 1996; Schärer et al. 1996; Rubatto et al. 2009).

The Alpine accretionary wedge is characterised by distinct domains of similar pressure and temperature conditions but different ages (Fig. 2). The proposed depth of metamorphism is deduced from $\mathrm{p}$-t estimates. Our observations do not allow a distinction between the lithostatic pressure and the tectonic overpressure suggested in the models of Petrini \& Podladchikow (2000), Mancktelow (2008) and Schmalholz \& Podladchikov (2013). Between 90 and 30 Ma, the Sesia zone, the Piemont oceanic crust, the Briançonnais continental crust, the Valais basin and the southern European crust were successively subducted, extruded and accreted in the huge zone of Alpine subduction and collision as the result of the southeast-directed European plate underthrusting below the Adriatic plate (Fig. 12). The Late Cretaceous to Early Paleocene Sesia underthrusting, extrusion and accretion at the front of the Adriatic plate occurred to the south of the Piemont ocean basin, before its closure during the Paleocene-Early Eocene. This was followed by the underthrusting and rapid extrusion of the Piemont oceanic crust and mantle and the southern Briançonnais (Prepiemont) continental Mont Fort, Portjengrat, Monte Rosa units between 50 and $38 \mathrm{Ma}$ (Lapen et al. 2003; Bucher et al. 2005). The occurrence of coesite in the Zermatt-Saas Fee ophiolites in the Lago Cignana region testifies that these rocks were subducted down to at least $90 \mathrm{~km}$ depth (Reinecke 1998). Angiboust et al. (2009) determined homogeneous peak burial conditions with temperatures around $540 \pm 20^{\circ} \mathrm{C}$ and pressures of $23 \pm 1 \mathrm{kbar}$ throughout the $60 \mathrm{~km}$ wide Zermatt-Saas ophiolite unit. Bucher et al. (2005) calculate the P-T conditions at $\sim 2.5-3.0 \mathrm{GPa}$ and $\sim 550-600{ }^{\circ} \mathrm{C}$. The latter suggest that the antigorite breakdown in the serpentinites that released large amounts of dehydration water in the subducted serpentinites slab (Ulmer and Trommsdorff 1995) facilitated exhumation of the Zermatt-Saas eclogites and blueschists. Lapen et al. (2003) describe a prograde garnet growth between 50 and $38 \mathrm{Ma}$ associated with $\mathrm{P}-\mathrm{T}$ conditions ranging from 1.0 to $2.8 \mathrm{Gpa}$ and 410 to $620^{\circ} \mathrm{C}$. These data involve average burial rates ranging from $0.47 \pm 0.03 \mathrm{~cm} / \mathrm{a}$ at $1.0 \mathrm{Gpa}$ to $0.23 \pm 0.02 \mathrm{~cm} / \mathrm{a}$ at $2.8 \mathrm{Gpa}$ followed by an extremely rapid exhumation rate of 10-26 km/Ma. Buoyancy forces acting on the low-density serpentinites $(\mathrm{D}=2.5-2.6)$ of the ophiolites and on the Monte Rosa and Portjengrat granite $(\mathrm{D}=2.7)$ probably played a major role in the rapid extrusion of these units. Several models suggest buoyancy-driven transport of UHP rocks from the subduction conduit (e.g., Chemenda et al. 1995; Butler et al. 2013). The garnet and glaucophane mineral assemblage indicates in the Tsaté nappe high-pressure greenschist facies conditions that did not exceed 0.8-1.0 GPa of pressure for a maximum temperature of $400 \pm 50^{\circ} \mathrm{C}$ (e.g., Ballèvre and Merle 1993; Reddy et al. 1999; Negro et al. 2013). These P-T conditions clearly contrast with the ultra high-pressure eclogitic conditions observed in the Zermatt-Saas Fee nappe (26-28 kbar and $600{ }^{\circ} \mathrm{C}$, Reinecke 1998) testifying that these two parts of the Piemont oceanic crust subducted to different depths before their extrusion and accretion to the Sesia and Adria indenter. Engi et al. (2001) propose pressures of 10-15 kbars and temperatures of $600-750{ }^{\circ} \mathrm{C}$ for the high pressure metamorphism of the Monte Rosa gneisses and pressures of 10-12 kbars and temperatures of $600-730{ }^{\circ} \mathrm{C}$ for the Barrovian metamorphism of the Monte Rosa gneiss situated to the East of the Ossola valley.

Relicts of an eclogitic schistosity and mineral lineation are locally preserved at Mellichen and the Spitze Flue in the upper Täsch valley (Fig. 3; Steck 1989; Ring and Merle 1992). Steck (1989) suggested, that the eclogitic E-W trending mineral lineation could belong to the same phase as the W-directed Cretaceous shear structures of the Austrian Alps (Ratschbacher 1987). The mineral lineation is oriented parallel to the younger stretching lineation XIV. An E-W mineral lineation was also described in eclogite boudins of 
the Adula nappe situated to the east of the Lepontine dome by Meyre and Puschnig (1993), Partzsch (1998), Kurz et al. (2004) and Cavargna-Sani et al. (2014). The similar orientation of the eclogite lineation in the Western, Central and Eastern Alps raises the question of a common CretaceousEocene deformation phase. However, no shear indicators related to the extrusion of the Late Cretaceous and Eocene high-pressure rocks are observed. Intense Oligocene and Neogene deformation and crystallisation obliterated generally early schistosity. The deformational structures reported on the tectonic and structural maps and cross-sections of the Monte Rosa region (Figs. 3, 4, 13, 14, 15, 16, 17) result

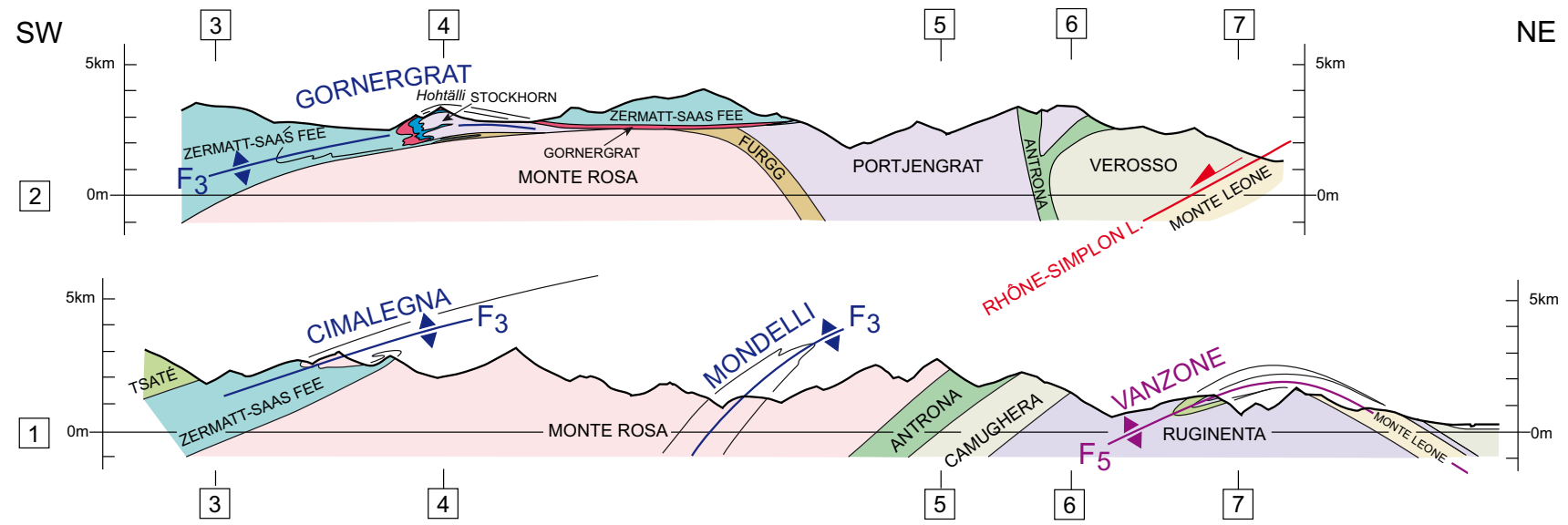

Fig. 13 SW-NE oriented structural cross-sections through the Monte Rosa nappe (for locations, see Fig. 3)

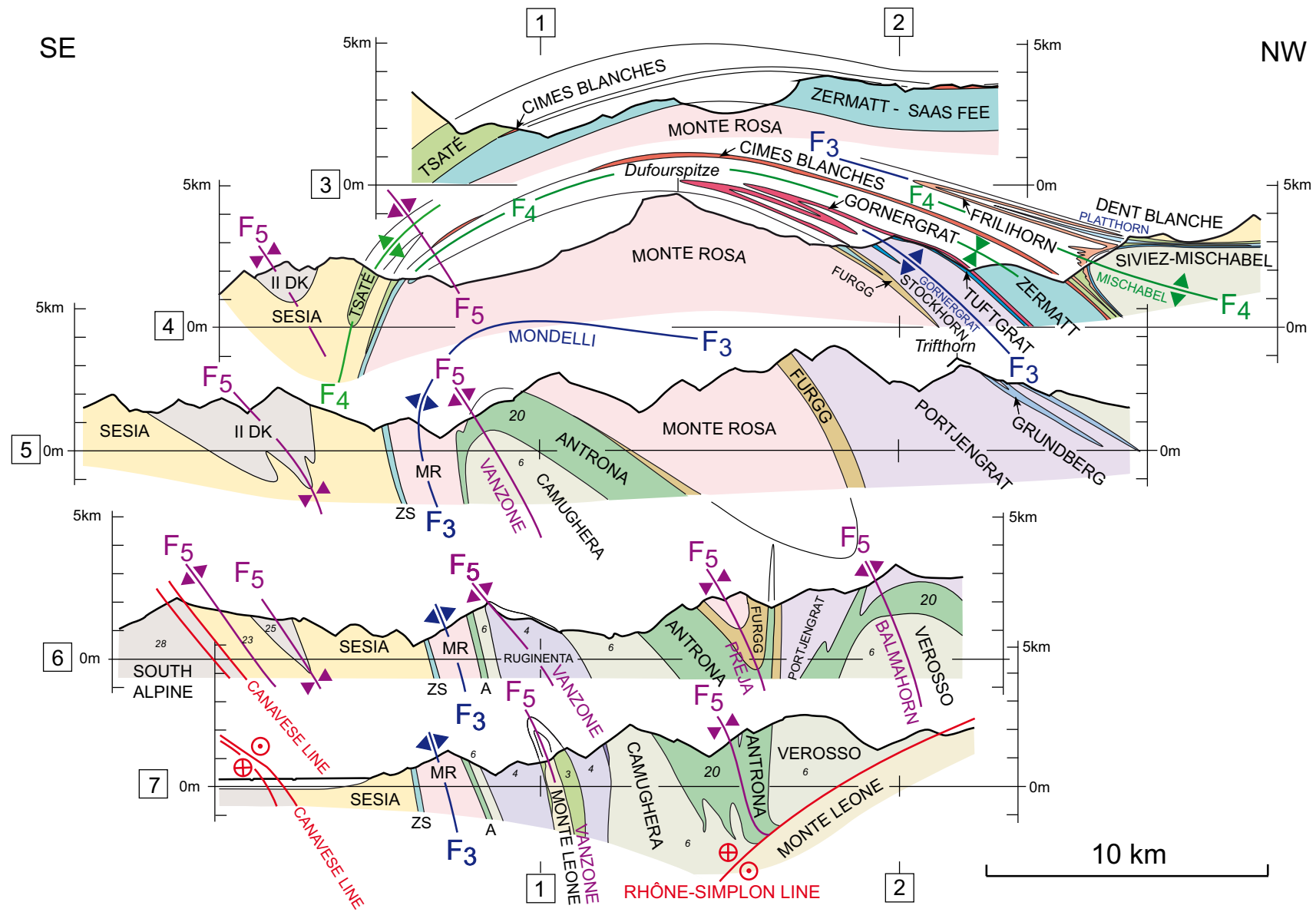

Fig. 14 SE-NW oriented vertical cross-sections through the Monte Rosa nappe, seen in the $46^{\circ} \mathrm{SW}$-plunging Vanzone fold axis direction (for locations, see Fig. 3). (II DK) Seconda Zona Diorito-Kinzigitica, (MR) Monte Rosa nappe 


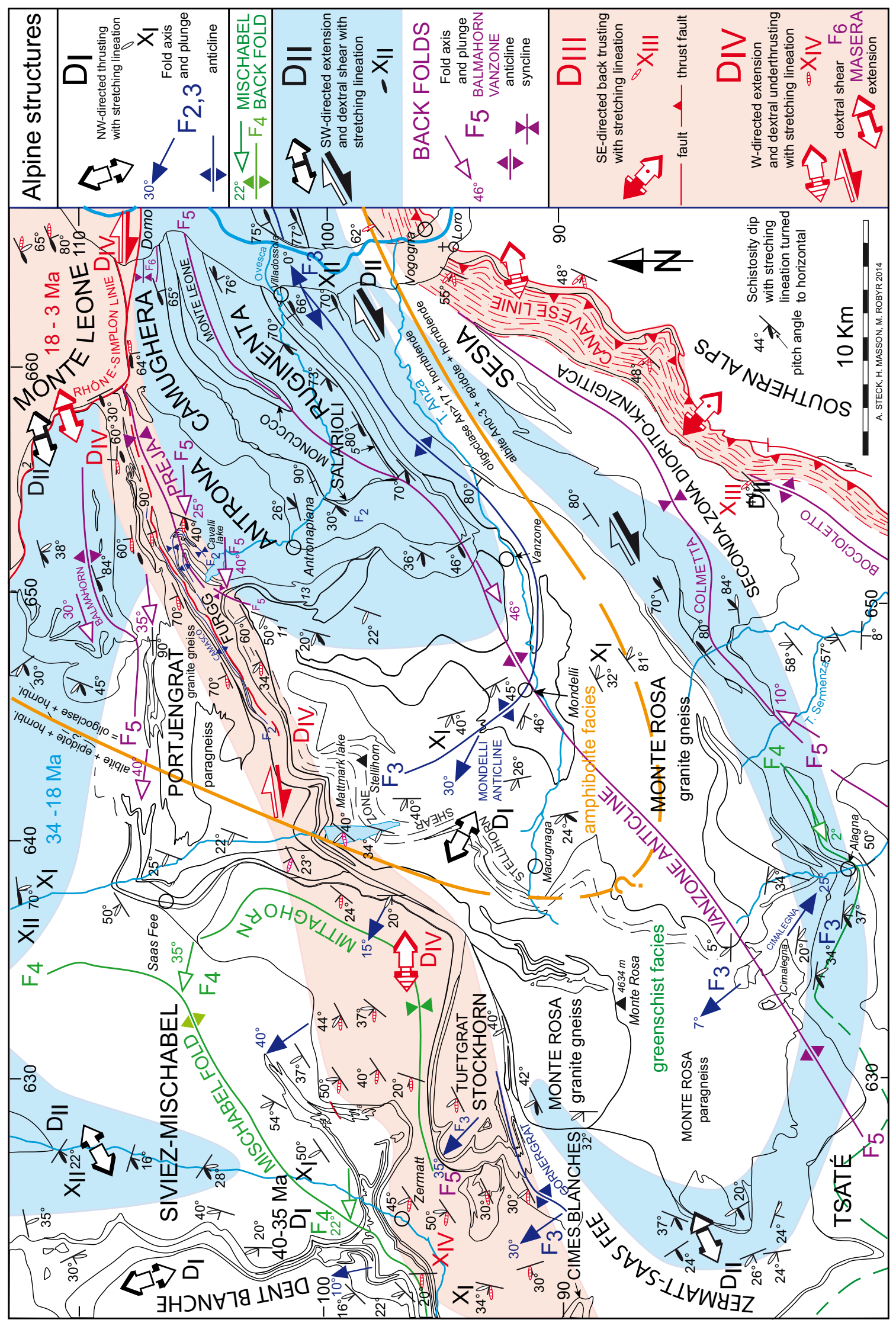


4Fig. 15 Structural map of the Monte Rosa and surrounding nappes, Figs. 10 (Gornergrat section) and 11 (Mischabel backfold) illustrate complex interference structures only observable at a local scale

mainly from the Late Eocene to Neogene Alpine continental collision. The superposition from base to top of the highpressure oceanic Zermatt-Saas Fee, continental Cimes Blanches, oceanic Tsaté and continental Dent Blanche nappes is an enigmatic Alpine structure; it will be discussed in the kinematic model of chapter 4 .

\subsection{Middle Eocene to Neogene underthrusting of the European Plate below the Adriatic indenter, nappe formation, post-nappe folding and dextral transpressional deformations}

In this chapter we discuss the main NW-directed trusting phase DI, the Mischabel and Neubrück F4 backfolds, the younger $\mathrm{SW}$-oriented high-temperature dextral shear phase DII structures and related Vanzone backfolding F5, that post-date the S-directed Cimes Blanches flake detachment and overthrust and the younger retrograde deformation phases DIII and DIV (Figs. 15, 16, 17, 18, 19, 20, 21).

\subsubsection{The NW-directed thrusting and deformation period DI}

Three schistosities S1-S3 developed during the NW-directed thrusting period DI. The oldest schistosity S1 is subparallel to the stratification and thrust planes. It is difficult to recognise and is often obliterated by the younger deformations. The view on the Mischabel backfold above Zermatt illustrates the three phases of deformation related to the NW-directed thrusting DI (Fig. 11). Only the thrust of the Cimes Blanches on the Zermatt-Saas Fee nappe is older and related to the S-directed flake detachment (see chapter 4). The thrust surfaces S1 are folded by second F2 and third F3 folds prior to the F4 Mischabel backfold. The distinction of the three schistosities S1-S3 is very difficult in the gneisses and in the basal mylonitic thrust zone of the Dent Blanche nappe (Fig. 11) and only the main

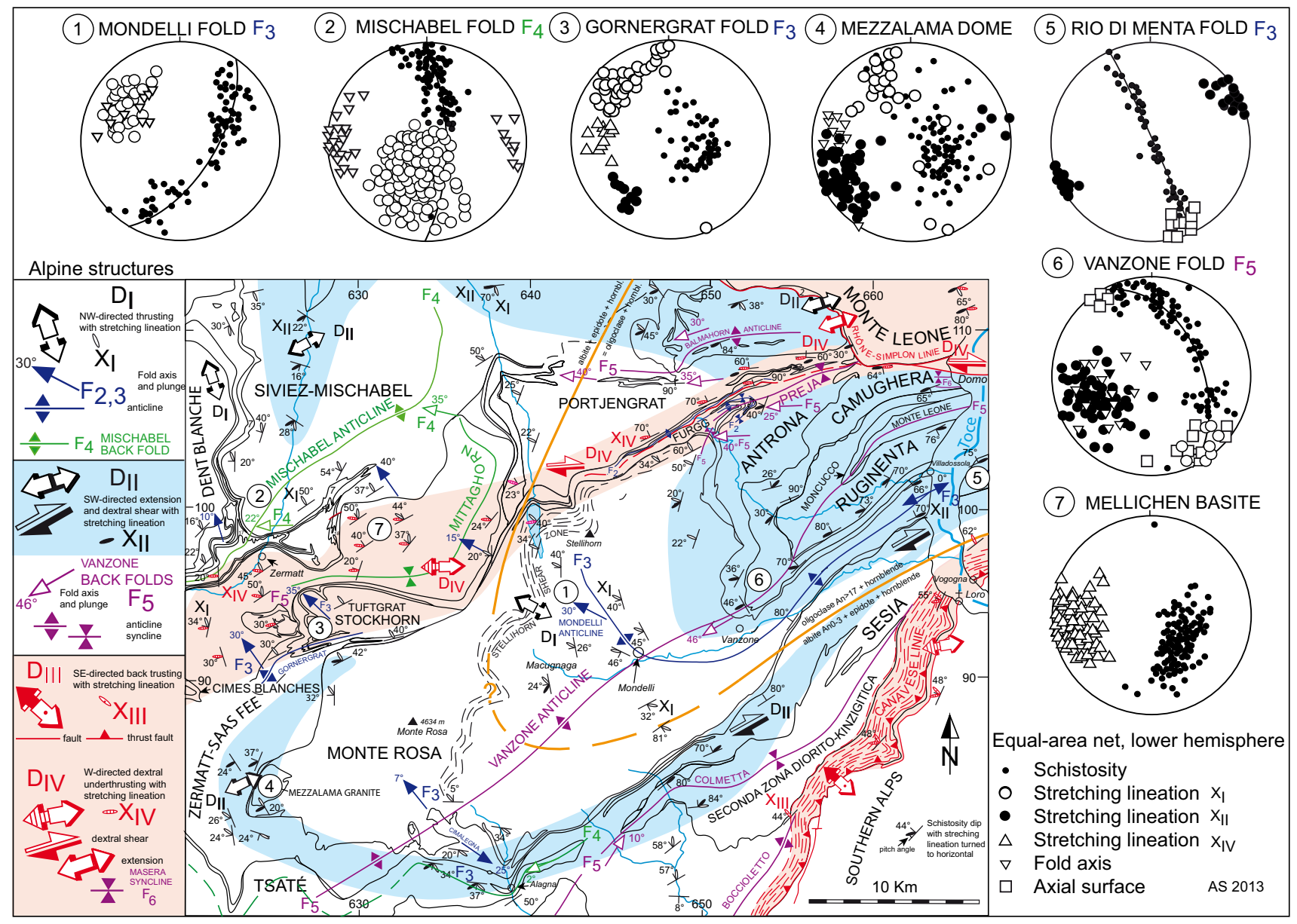

Fig. 16 Structural map 1 of the Monte Rosa nappe with stereograms of typical Alpine structures 


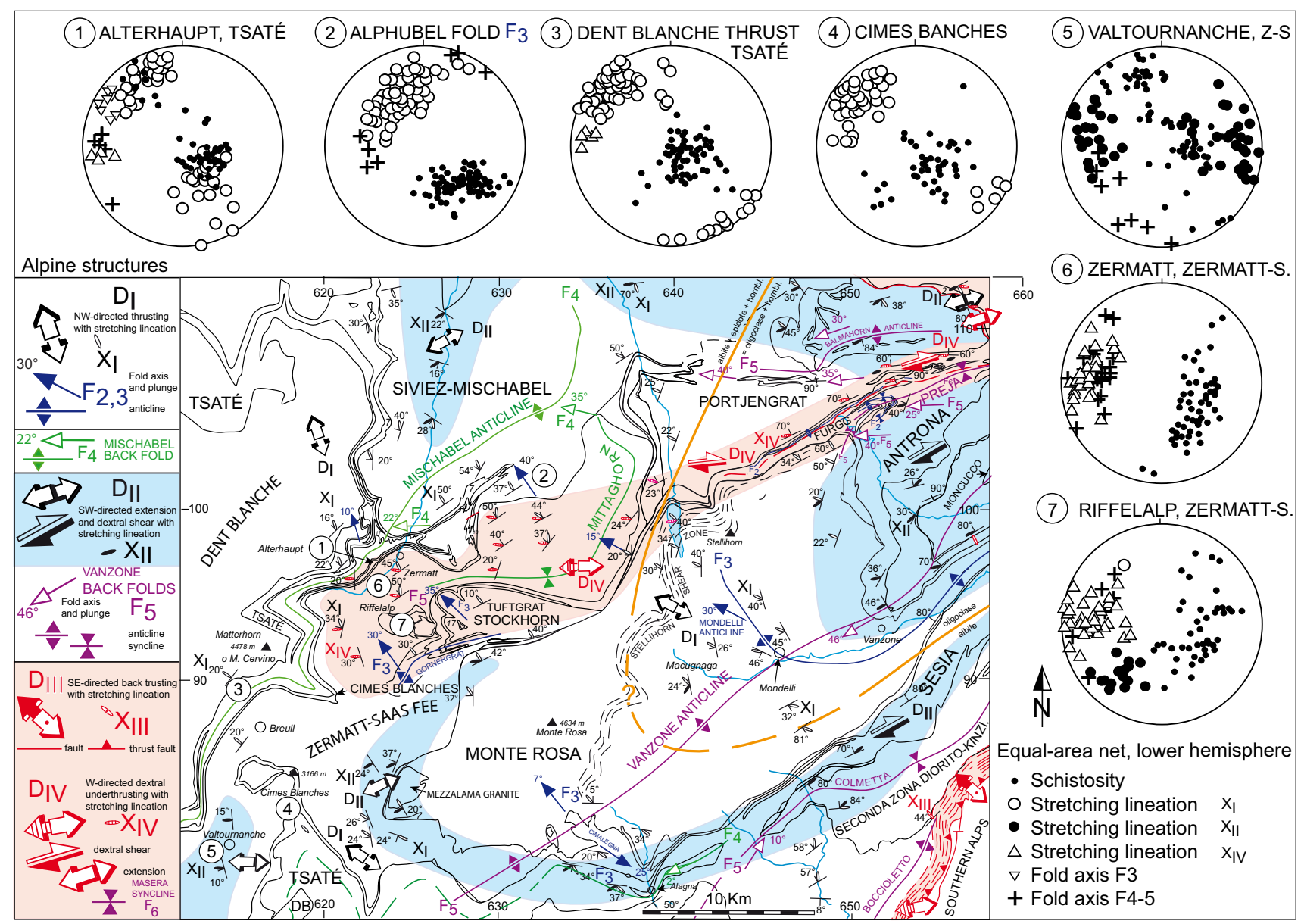

Fig. 17 Structural map 2 of the Monte Rosa nappe with stereograms of typical Alpine structures

schistosity (S2 and/or S3) was represented on Figs. 3, 15, 16 and 17. Note that in the Alpine literature the main schistosity and the main phase of NW-verging folding and thrusting are often noted FA1, S1 and FA2 and S2 (Table 1; Huber et al. 1980; Ramsay in Steck et al. 1979; Klein 1978; Grujic and Mancktelow 1996; Maxelon and Mancktelow 2005). We don't follow this simplification (e.g., Steck 1984, 1990). The distinction of the parallel SE-NW stretching lineations as L1, L2 or L3 and their attribution to the schistosities S1, S2 and S3 is only rarely possible. For this reason the SW-NE oriented stretching lineations, related to the three schistosities with top-to-NW shear indicators, are designated together as XI (XI corresponding to the great axis of the deformation ellipsoid). They are related to the first period of NW-directed thrusting DI that includes several phases of NW-directed thrusting and folding (Table 1). The second S2 and third S3 schistosities with their NW-SE-oriented stretching lineation called XI and associated top-to-NW shear indicators are the main deformational structures of the Penninic nappes (Figs. 3, 15, 16, 17; Steck 1980, 1984, 1990,
2008; Steck and Hunziker 1994; Lacassin 1984, 1989; Lacassin and Mattauer 1985; Steck et al. 2013). Also the main deformational structures of the Stellihorn shear zone in the northern Monte Rosa nappe belong to this phase of NW-directed thrusting DI (Lacassin 1984, 1989; Steck 1984, 1990; "Mattmark phase" of Pleuger et al. 2008; Table 1). It is suggested that these DI phase deformational structures have been formed by ductile detachment of the upper Briançonnais and European crust during their Tertiary SE-directed underthrusting below the Adriatic plate (Steck 1990; Epard and Escher 1996; Escher and Beaumont 1997). Fold axes were reoriented parallel to the main SE-NW direction of extensional shearing by rock internal rotation. Such F2 and F3 folds, with their NW-oriented axes like the Platthorn F3 fold to the north of Zermatt (Fig. 11, Alterhaupt fold, Stereogram 1 on Fig. 17; Sartori 1987) and the Stockhorn-Gornergrat F3 fold south of Zermatt (Figs. 3, 10, 13, 14 and stereogram 3 on Fig. 16) have a same SW-vergence. This reveals a component of dextral transpression during the NW-directed overthrusting (Steck 1989). The Cimalegna F3 fold to the north of 


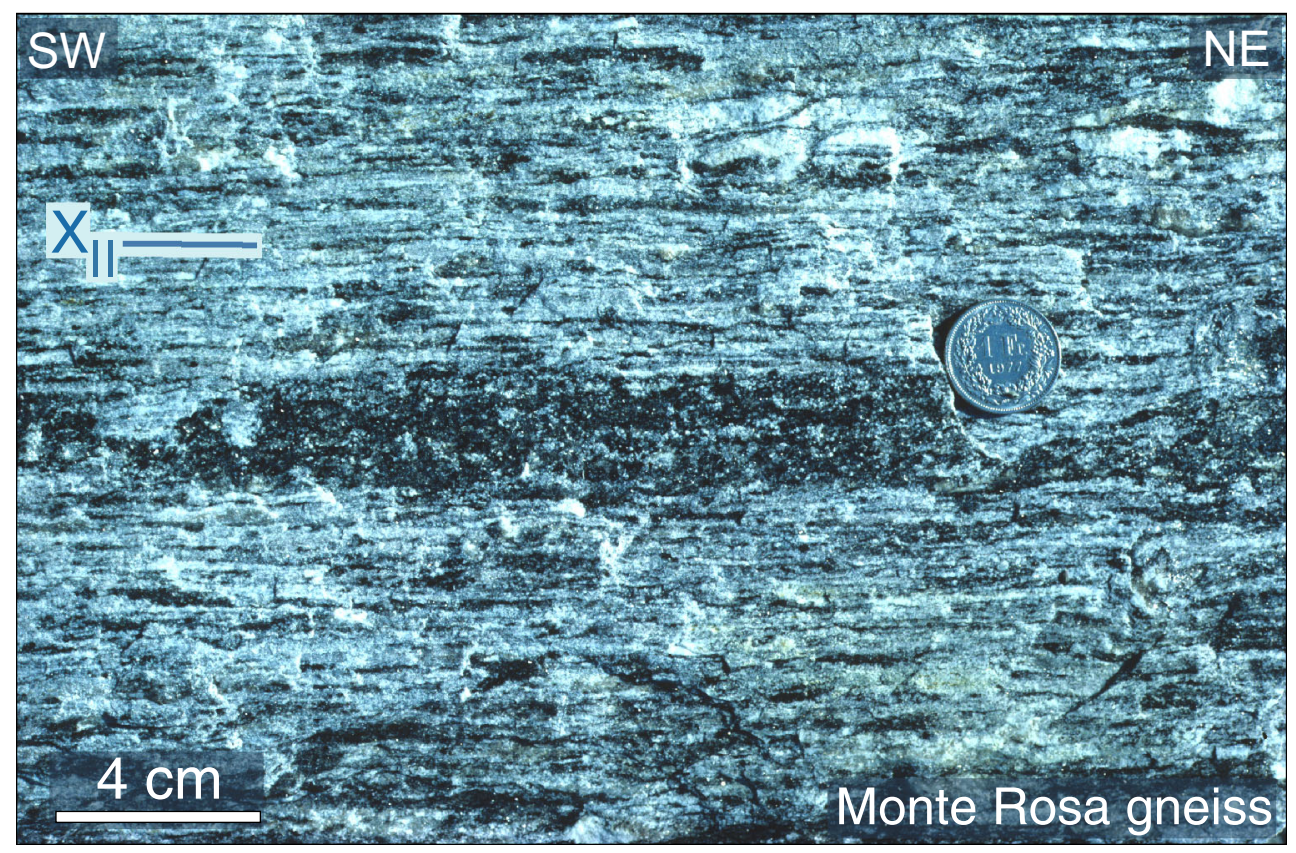

Fig. 18 Monte Rosa granite gneiss from Villadossola with stretching lineation XII, view on the schistosity plane (Ovesca river-bed, Swiss map coordinates: $663.3 \mathrm{~km} / 102.0 \mathrm{~km} / 250 \mathrm{~m}$ )

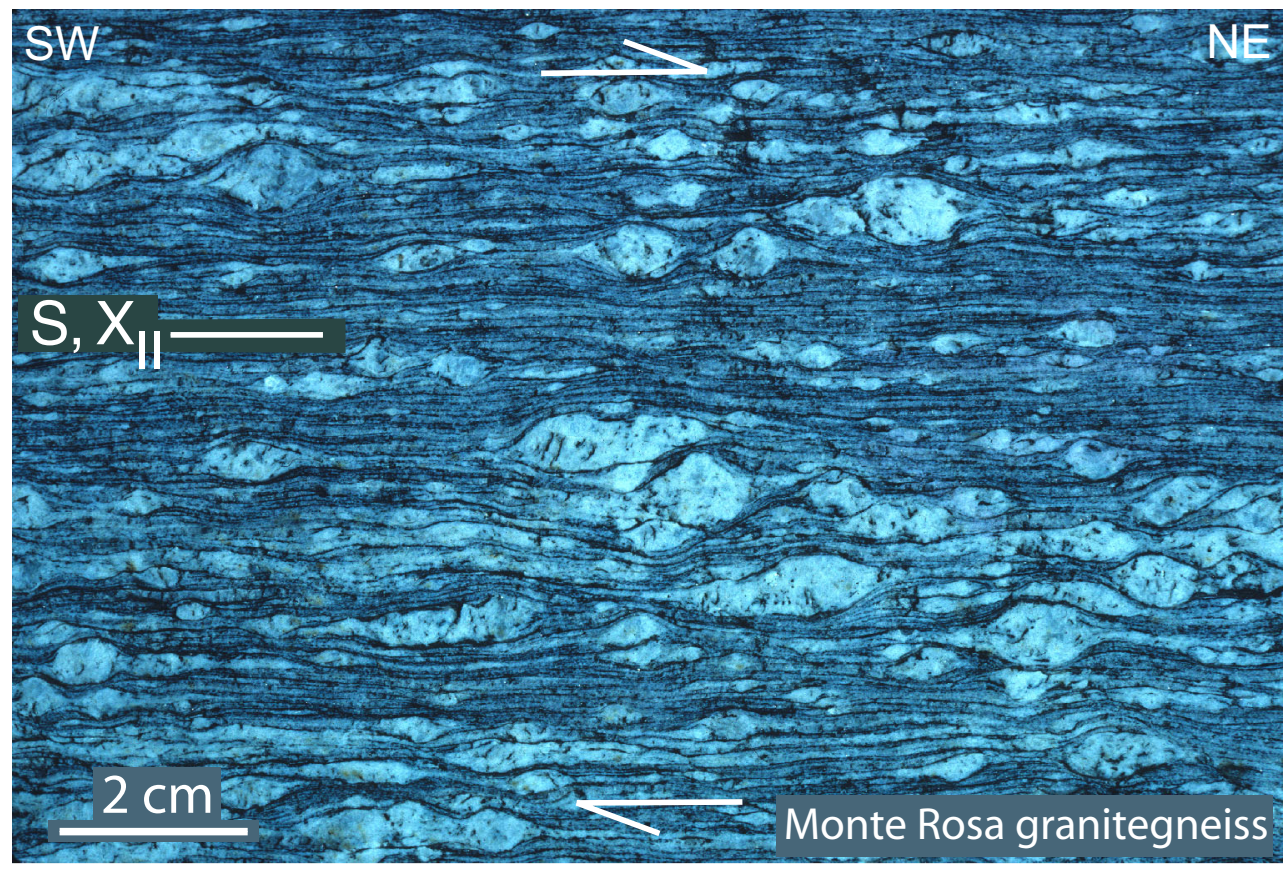

Fig. 19 Monte Rosa granite gneiss from Villadossola in Ovesca riverbed with stretching lineation XII, surface perpendicular to the schistosity plane and parallel to the stretching lineation XII. Sigma- type deformed K-feldspar porphyroclasts with K-feldspar growth in pressure shadows indicate dextral shear deformation under amphibolite facies conditions
Alagna-Valsesia characterised by low angle NW- or SEplunging fold axis and stretching lineation has a similar SW-vergence as the Platthorn and Gornergrat folds and belong likely to the same deformation phase (Figs. 3, 11, 13, 14, 15; Gosso et al. 1979; Pleuger et al. 2005, 2008).
Only the Mondelli F3 recumbent anticline, in the centre of the Monte Rosa nappe is NE-facing (Figs. 3, 15 and stereogram 1 on Fig. 16). Mondelli is the name of a hamlet and chapel in the Anzasca valley situated on the axial trace and with a good view on the huge fold hinge. The axial 


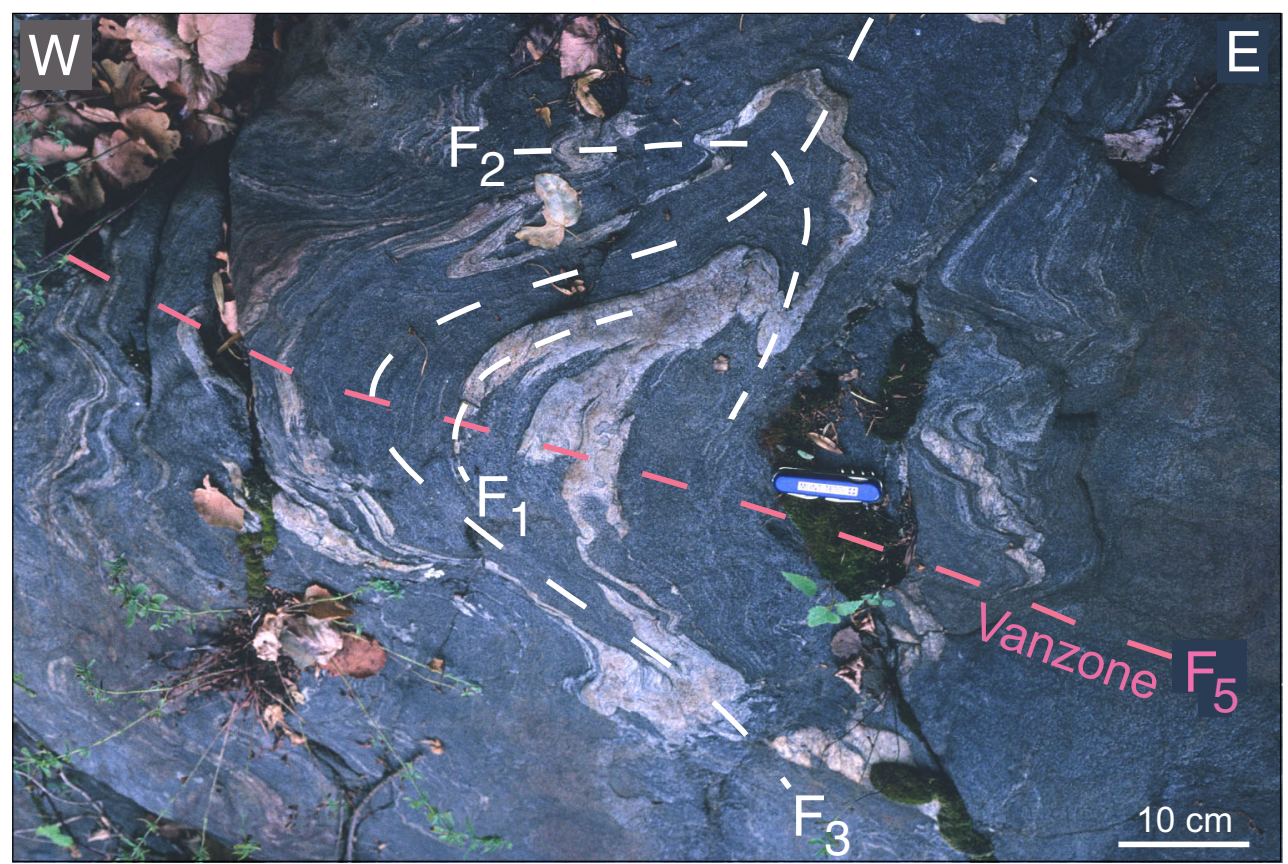

Fig. 20 "Mushroom-shaped", multiple Type 2 fold interference pattern (after Ramsay 1967) in hornblende-biotite-plagioclase-gneiss of the Ruginenta unit, from the hinge zone of the Vanzone anticline
F5 overprinting older F1-2-3 folds (Ovesca river-bed outcrop near Ruginenta, Swiss map coordinates: 657.0 km/99.6 km/575 m)

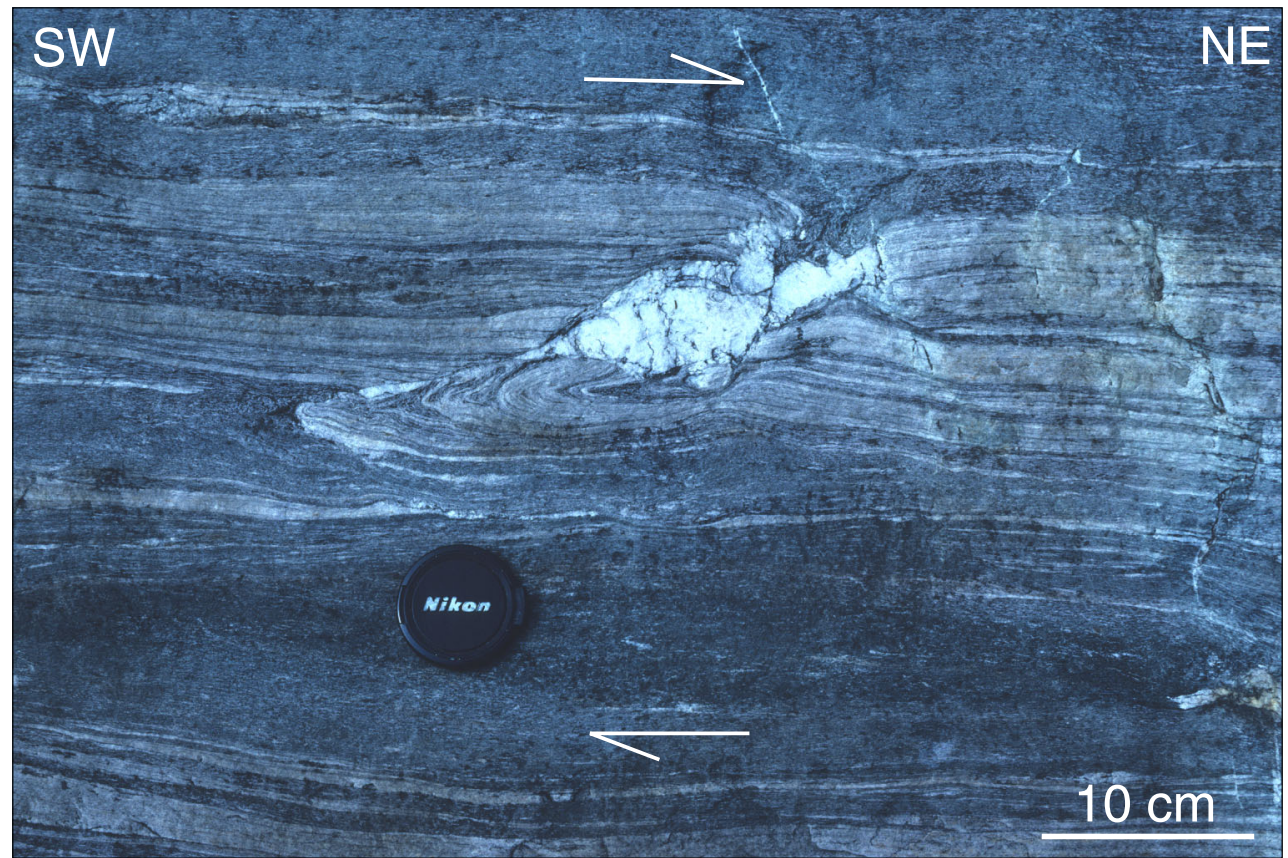

Fig. 21 Same locality as Figs. 18 and 19. Amphibolite of the Antrona zone on the northern border of the Monte Rosa gneiss. Boudinage of a competent plagioclase rich layer with quartz and

surface schistosity is a third schistosity S3 refolding two older schistosities $\mathrm{S} 1$ and $\mathrm{S} 2$ in the Rio di Menta fold (stereogram 5 on Fig. 16; Reinhardt 1966; Steck 1984). chlorite growth in a clock-wise rotated extensional joint and drag folds demonstrate the continuation of dextral shear under retrograde greenschist facies conditions during DIV deformation

The NW-directed thrusting of the Dent Blanche nappe is younger than the youngest sediments of its footwall, i.e., the Middle Eocene flysch of the Siviez-Mischabel nappe. 
The NW-directed thrusting of the Siviez-Mischabel nappe was dated by Markley et al. (1998) with the ${ }^{40} \mathrm{Ar}-{ }^{39} \mathrm{Ar}$ dating on synkinematic white micas from the Triassic of the Siviez-Mischabel nappe at 40-35 Ma.

\subsubsection{The Mischabel backfold, F4}

The Mischabel backfold F4 (Figs. 11, 14 and stereogram 2 on Fig. 16) deforms the pre-existing thrust planes, S1-S3 schistosity and XI stretching lineation. Milnes et al. (1981) and Müller (1983) studied the geometry of the Mischabel anticline and Mittaghorn syncline. These S-verging folds are coeval with the $\mathrm{NW}$-directed frontal thrusts of the Middle and Lower Penninic nappes (Escher et al. 1988, 1993; Escher and Beaumont 1997). Neither dextral shear structures, nor a stretching lineation parallel to the F4 fold axis are observed in the Mischabel backfold. Pleuger et al. (2008) attributed NW- or SE-plunging stretching lineations with top-to SE shear indicators of backthrusting in the Vanzone fold hinge to his "Mischabel phase". Another backfold that deforms the limit of the Sion-Courmayeur unit and the Zone Houillère situated at Neubrück between Stalden and Visp is attributed to the same phase of backfolding F4 (Fig. 4). The north-closing syncline exposed at the Passo della Preja, belongs probably to the same backfolding phase F4 as the Mischabel backfold (Fig. 6).

\subsubsection{SW-striking dextral-shearing DII, backfolding F5 and formation of the southern steep belt of the Central Alps}

The NW-directed thrusting parallel to the stretching lineation XI was overprinted by SW-striking dextral ductile shear zones during a younger phase of dextral transpression characterized by a SW-plunging stretching lineation XII (Figs. 18, 19). The main dextral shear zone during this DII deformation period is the Simplon ductile shear zone (represented in blue on Figs. 2, 15, 16, 17). It crosses the whole Penninic and Austroalpine nappe stack from the Canavese line near Locarno and the Centovalli and Valle Vigezzo to the east, through the Simplon pass and reaches the Rhone valley west of Visp in the front of the Siviez-Mischabel nappe (Steck 1980, 1984, 1990; Steck and Hunziker 1994; Steck 2008; Steck et al. 2013). During on-going dextral shearing, the whole Penninic nappe stack was deformed by the younger SE-facing Vanzone F5 anticline, termed Argand's "Insubric phase" of backfolding in the Alpine literature (Figs. 3, 4, stereogram 6 on Figs. 16, 20). The Vanzone fold deforms the axial trace of the Mischabel backfold (Figs. 3, 20 and geological Sect. 4 on Fig. 14). The Vanzone F5 anticline developed during a late phase of the still on-going dextral ductile shearing DII. This dextral, top-to-SW shear zone collectively overprints the Ruginenta,
Camughera, Zermatt-Saas Fee and Monte Rosa units in the hinge of the Vanzone anticline, between Antronapiana and the village of Vanzone. The stretching lineation XII is oriented parallel to the $46^{\circ} \mathrm{SW}$-plunging Vanzone fold axis F5 (Steck 1984, 1990; Steck and Hunziker 1994; Figs. 3, 15, 16, 18, 19, stereograms 4, 5 and 6 on Fig. 16 and stereograms 5 and 7 on Fig. 17). The axial trace of the Vanzone anticline continues from the evident fold hinge to the north of the village of Vanzone in a NE-direction, crosses the Ovesca river at the bridge branching to Ruginenta (Fig. 20), continues through the marble fold hinge of Alpe Pradurino, then passes south of the Moncucco summit, in the centre of the Moncucco granite gneiss to the "Calvario" church south of Domodossola (Fig. 3; Milnes et al. 1981; Steck et al. 1999; Pleuger et al. 2005; Steck 2008). These field observations are different from the structural interpretation of the Vanzone fold published by Keller et al. (2005), that has to be revised. A similar dextral shear zone (also in blue on Figs. 15, 16, 17) is exposed parallel to the southern contact of the Monte Rosa nappe and forms top-to-SW detachment structures in the porphyritic Mezzalama granite gneiss and the overlying Zermatt-Saas Fee ophiolites (stereogram 4 on Fig. 16; Le Goff (1986) in Ballèvre and Merle 1993; Steck 1990). These dextral ductile shear zones DII developed between ca. 34 and 18 Ma (Figs. 3, 15; Steck and Hunziker 1994; Romer et al. 1996; Schärer et al. 1996; Markley et al. 1998; Steck 2008; Steck et al. 2013). The dextral shearing DII, the Vanzone backfolding and the steepening of the southern root of the Penninic nappes were formed under high temperature amphibolite facies conditions (Steck and Hunziker 1994; Engi et al. 2001; Keller et al. 2005; Steck 2008; Steck et al. 2001, 2013). The synmetamorphic Vanzone anticline (Figs. 2, 3, 4, 15, 16, 17; Steck et al. 2001) folded the greenschist facies-amphibolite facies isograd, defined by the reaction: albite An0-3 + epidote + hornblende = oligoclase An17 + hornblende (Wenk and Keller 1969; Steck et al. 2001). A marked change in the style of the F5 Vanzone anticline is observed from the SW to the NE. Whereas the Vanzone anticline forms an open concentric F5-fold north of Alagna-Valsesia, the fold geometry is transposed into a squeezed fold with parallel fold limbs to the east in the Toce valley (Figs. 1, 3, 15, 16, 17; Steck 2008). This modification in the geometry of the fold results from squeezing related to an increase of rock ductility from the low temperature, greenschist facies conditions on the roof of the Monte Rosa nappe, to the high temperature, amphibolite facies grade rocks in the Toce valley. The "golf club" shaped geometry of the Monte Rosa nappe results from this increase of deformation intensity from the large frontal fold to the root zone of the nappe (Figs. 1, 2, 3, 14, $15,16,17)$. The cooling from west to east of the Monte Rosa nappe by uplift and erosion to temperatures lower than $650-600{ }^{\circ} \mathrm{C}$ was dated with LA PMMS U-Pb monazite 
ages by Engi et al. (2001) at 45-40 \pm 3 Ma at Macugnaga, $42-40 \pm 1 \mathrm{Ma}$ at Antronapiana and $33-31 \pm 1 \mathrm{Ma}$ in the Toce Valley. Nearly isothermal decompression induced sillimanite crystallization in the high-grade staurolite and kyanite bearing rocks west of Domodossola (Keller et al. 2005). ${ }^{40} \mathrm{Ar}-{ }^{39} \mathrm{Ar}$-ages on hydrothermal muscovite of goldquartz veins indicate farther cooling of the Vanzone anticline below $300{ }^{\circ} \mathrm{C}$ at $31.6 \pm 0.3 \mathrm{Ma}$ in the Brusson window (9 on Fig. 1) and 32.4 Ma near Quarazza, 29.0 Ma at Pestarena (these three localities are situated to the SW of the map Fig. 3). The same method of dating yields farther to the NE consistent younger ages of $24.5 \mathrm{Ma}$ at Alpe Trivera south of Antronapiana and 11.6 Ma on the Rhone-Simplon line in the Zwischbergen Valley above Gondo (Fig. 3; Pettke et al. 1999). These ${ }^{40} \mathrm{Ar}-{ }^{39} \mathrm{Ar}$ muscovite ages corroborate the $\mathrm{K} / \mathrm{Ar}$ and $\mathrm{Rb} / \mathrm{Sr}$ white mica and biotite cooling ages already obtained by Hunziker (1969), Hunziker and Bearth (1969), Hunziker et al. (1992), Steck and Hunziker (1994) and Steck et al. (2013) on the same profile. The rapid cooling of the amphibolite facies Vanzone anticline in the Toce transect to 650 and $300{ }^{\circ} \mathrm{C}$ at $32-30$ and $10 \mathrm{Ma}$ respectively, was accompanied by uplift, tectonic denudation and erosion of the Lepontine dome structure. This uplift phase occurred contemporaneously with dextral shearing along the ductile Simplon shear zone DII ( 34 to $<25 \mathrm{Ma}$ ). The timing of this dextral shearing is inferred from the ages of the mantle derived andesite and tonalite (32-29 Ma) and synkinematic crustal aplite and pegmatite intrusions in the southern steep belt between Domodossola and Locarno. Dextral shear occurred before the andesite intrusions and continued before, during and after the synkinematic aplite and pegmatite intrusions dated at 29-25 Ma (Steck and Hunziker 1994; Romer et al. 1996; Schärer et al. 1996; Steck et al. 2013).

\subsubsection{Brittle normal detachment on the Rhone-Simplon line and continuation of dextral shear DIII and DIV under retrograde metamorphic conditions}

On-going cooling by uplift and erosion of the Lepontine dome at temperatures below $\sim 300{ }^{\circ} \mathrm{C}$ marked the onset of brittle normal faulting on the Rhone-Simplon line that is superimposed to the earlier Simplon ductile shear zone DII (blue on Figs. 2, 15, 16, 17; Simplon dextral shear DII and DIV on Table 1). In contrast, a ductile shear DIV still occurs in the hot footwall of the Simplon shear zone (represented in red on Figs. 2, 15, 16, 17). This brittle lowangle normal fault detachment on the Rhone-Simplon line was dated by the $\mathrm{Rb}-\mathrm{Sr}$ and $\mathrm{K}-\mathrm{Ar}$ methods on muscovite and biotite and the zircon and apatite fission track method at 18-3 Ma (Hurford 1986; Hunziker and Bearth 1969; Soom 1990; Steck 1984, 1990, 2008; Mancktelow 1985, 1990, 1992; Hunziker et al. 1992; Steck and Hunziker
1994; Campani 2011; Steck et al. 2013). A steep NWplunging stretching lineation XIII associated with top-to-S thrust structures developed during backthrusting DIII on the Canavese inverse fault (Figs. 3, 15, 16, 17). The amphibolite facies dextral shear DII is extended toward the south in the southern steep belt of the Central Alps. Here the dextral shearing (DIV) develops under retrograde greenschist facies to non-metamorphic conditions of deformation (represented in red on Figs. 15, 16, 17). Another greenschist facies to anchizonal dextral shear and underthrust zone DIV, ending with brittle shear structures and fault gauges (kakirites, Svenonius 1892 in Higgins 1971), crosses the Alps from the Centovalli and Valle Vigezzo to the east of Domodossola (Domo on Fig. 3), through the Bognanco and Loranco valleys to the region of Zermatt to the west (Fig. 3, DIV on Figs. 3, 15 and stereogram 7 on Fig. 16). Illites, from nine fault gauges of the Centovalli Line were dated with the K-Ar method of 14-4 Ma by Surace et al. (2011), completing the 9.1-8.3 Ma ages of Zwingmann and Mancktelow (2004). The over two kilometre wide dextral zone of shear and underthrusting DIV in the southern Sesia zone and the Ivrea zone south of the Canavese line, designated as "schisti di Fobello e Rimella" to the south-west of the Toce valley, was mainly formed under retrograde greenschist facies to non metamorphic conditions (Fig. 15). The mylonites are younger than the Oligocene intrusives (Schmid et al. 1989; Steck 1990). It is probable that this zone of mylonites overprints also older deformational structures of the Canavese line that are not distinguishable from the younger mylonites. The Canavese line that separates Cretaceous eclogites of the southern Sesia zone from Alpine greenschist facies structures in the Southern Alps border was certainly active since Cretaceous time. These older movements are attesded both by geochronology (see above Sect. 3.1) and by the sedimentation of the Late Cretacous flysch of the Simme nappe in the Prealps. The Dent Blanche depression to the west, the Lepontine dome to the east, separated by the Simplon ductile shear zone DII and the younger Rhone-Simplon low angle detachment DIV form together a pull-apart structure in the zone of dextral transpression between the European plate to the north and the Adriatic indenter to the south (Fig. 1; Steck 2008). The inclination, increasing from north to south of the $20^{\circ} \mathrm{SW}$-plunging Hübschhorn fold at the Simplon pass, the $30^{\circ} \mathrm{SW}$-plunging Balmahorn and $46^{\circ} \mathrm{SW}$-plunging Vanzone F5 folds result from the Central Lepontine dome uplift since $35-25 \mathrm{Ma}$ dated by radiometric cooling ages (Hurford 1986; Hunziker et al. 1992; Steck and Hunziker 1994; Pettke et al. 1999: Engi et al. 2001; Rubatto et al. 2009; Steck et al. 2013). Figure 22 represents the view from Croppo on the amphibolite facies Vanzone F5 anticline in the Moncucco summit, the Preja F5 syncline in the Bognanco valley and the large Toce 


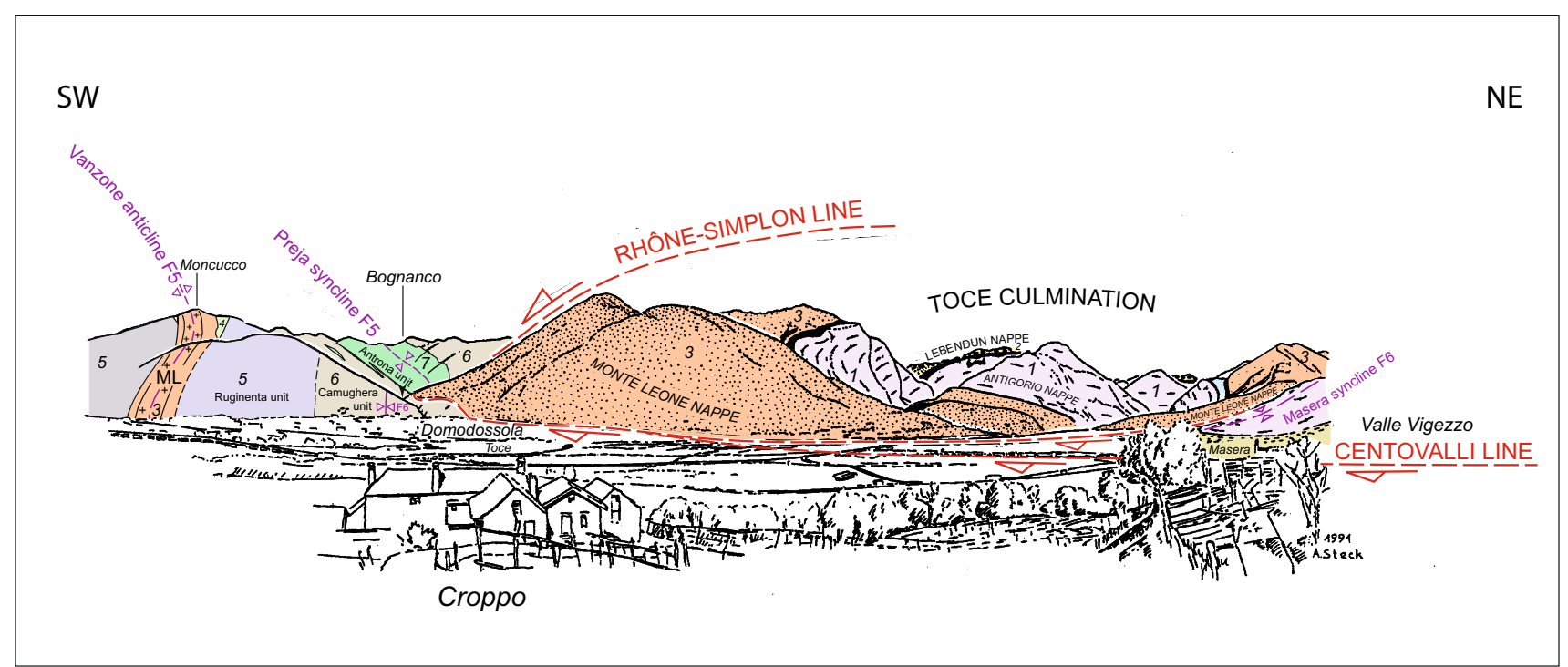

Fig. 22 View from Croppo on the Toce alluvial plain near Domodossola, the amphibolite facies Vanzone F5 anticline in the Moncucco summit and the Preja F5 syncline in the Bognanco valley,

culmination of the Lepontine gneiss dome situated in the footwall of the $30-36^{\circ} \mathrm{SW}$-dipping Rhone-Simplon normal fault. Figure 22 illustrates also the position of the Masera F6 syncline that was formed under retrograde greenschist facies conditions after cooling by uplift and erosion of the amphibolite facies Vanzone F5 anticline (Steck 2008; Steck et al. 2013).

\section{Model of the Tertiary kinematics of the Central Alps}

Already Argand (1916) (Figs. 1, 3, 4, 11, 14) observed the superposition, from base to top, of the oceanic ZermattSaas Fee unit, the continental Cimes Blanches and Frilihorn, the oceanic Tsaté and continental Dent Blanche nappes. Numerous authors discussed this remarkable Alpine tectonic structure (Argand 1916; Güller 1947; Bearth 1953, 1954a, b, 1964, 1978; Sartori 1987; Platt 1986; Escher 1988; Marthaler and Stampfli 1989; Vannay and Allemann 1990; Ring and Merle 1992; Ballèvre and Merle 1993). Platt (1986) and Ballèvre and Merle (1993) suggest that the exhumation of the high-pressure ZermattSaas Fee unit in the footwall of the Combin normal fault permitted the juxtaposition of these high-pressure metamorphic rocks with rocks from shallower levels (herein the Tsaté ophiolite nappe, Escher et al. 1988). Platt (1986) suggests that the formation of detachment faults occurred during on-going convergence in an orogenic accretionary wedge. In contrast, Ballèvre and Merle (1993) argue that, following the 100-90 Ma Eoalpine phase of deep the greenschist facies Masera F6 syncline and the large Toce culmination of the Lepontine gneiss dome situated in the foot wall of the $30-35^{\circ} \mathrm{SW}$-dipping Rhône-Simplon normal fault

subduction, an extensional event occurred between 80 and $60 \mathrm{Ma}$ leading to the reactivation of former crustal-scale thrusts as extensional detachments (e.g., Combin fault). This extensional event would be followed by a Mesoalpine phase of convergence between 45 and 40 Mas. New radiometric dating (Hunziker et al. 1992; Duchène et al. 1997; Ruffet et al. 1997; Rubatto et al. 1999; Steck and Hunziker 1994; Markley et al. 1998; Engi et al. 2001, 2004; Konrad-Schmolke et al. 2006; Babist et al. 2007; Rubatto et al. 2009; Janots et al. 2009) suggests a continuous succession of phases of subduction, extrusion and accretion in the Alpine accretionary wedge during the Adria-Europa convergence since about 90 Ma with a migration of the zones of subduction, extrusion and accretion from south to north (Fig. 12). However, the normal fault models of Platt (1986) and Ballèvre and Merle (1993) do not account for the presence of the continental Cimes Blanches unit at the limit of the ultra-high pressure Zermatt-Saas Fee with the greenschist facies Tsaté nappes. An alternative tectonic model that takes into account the presence of the Cimes Blanches nappe is developed hereafter. It is based on the Briançonnais affinity of the Triassic of the Gornergrat and Cimes Blanches units (see above Sect. 2.8). Note that the supposed SE-directed thrust of the Cimes Blanches nappe is not confirmed by deformational structures. For this reason it cannot be excluded that the Briançonnais type Cimes Blanches and Gornergrat units represent continental allochthons inside of the Piemont Ocean. The detailed mapping of the Cimes Blanches region by Vannay and Allemann (1990) and of the Mischabel backfold by Sartori (1987, 1990) (Fig. 11) and personal 


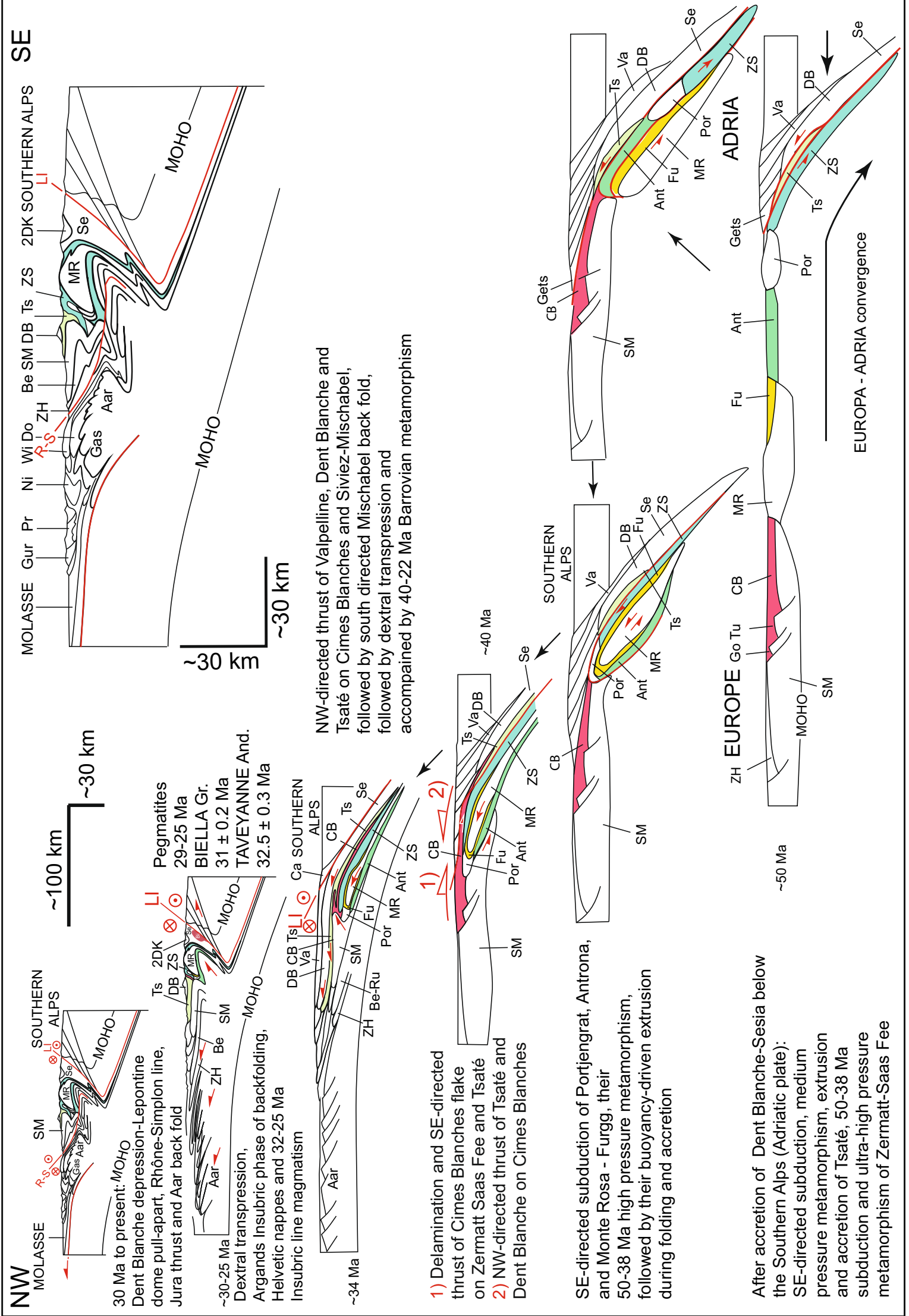


4Fig. 23 Model of the Tertiary kinematics of the Central Alps. The figure is not to scale. The relative paleogeographic position of the Cimes Blanches, Portjengrat and Monte Rosa continental units and the geometry of the Piemont oceanic basin are tentative

observations (Steck 1989) are used to propose a new kinematic model.

The proposed model (Fig. 23) is based on the assumption that in the Late Cretaceous, the Briançonnais (s.1.) continental was separated by the Piemont ocean from the Austroalpine Dent Blanche-Sesia continent to the south (Fig. 12).

A. The Adria-European plate convergence starts with the Late Cretaceous to Early Paleocene subduction, highpressure metamorphism, buoyancy driven extrusion and accretion of the Sesia zone to the Adriatic indenter (Hunziker et al. 1992; Duchène et al. 1997; Ruffet et al. 1997; Rubatto et al. 1998; Dal Piaz et al. 2001; Konrad-Schmolke et al. 2006; Babist et al. 2007; Handy et al. 2010).

B. It is followed by the Eocene subduction to various depths of the Piemont oceanic floor (Gebauer 1999; Amato et al. 1999; Lapen et al. 2003). The southern Tsaté nappe was overprinted by a high-pressure greenschist facies metamorphism at a pressure of 9 kbar and temperature of $400{ }^{\circ} \mathrm{C}$ (Ballèvre and Merle 1993), whereas the northern Zermatt-Saas Fee ophiolites were metamorphosed under ultra-high pressure conditions of over 26-28 kbar and $600{ }^{\circ} \mathrm{C}$ (Reinecke 1998; Bucher et al. 2005), then extruded by buoyancy forces and accreted to the Sesia-Adria plate margin.

C. The less-dense Cimes Blanches (and Frilihorn) continental flake was, during on-going Adria-BriançonnaisEurope convergence, detached by crustal delamination from its Briançonnais crust and overthrust toward the south on the extruded eclogite facies Zermatt-Saas Fee ophiolites and southern Tsaté ophiolites. The EtirolLevaz unit with its high-pressure metamorphism exposed farther south has a different, probably Austroalpine, origin (Dal Piaz 1992; Steck et al. 2001).

D. The southern part of the Briançonnais flake was during NW-directed thrusting imbricated as Frilihorn nappe into the Tsaté ophiolites, followed by the NW-directed Tsaté and Dent Blanche thrust over the Cimes Blanches and Zermatt-Saas Fee nappes (Figs. 3, 11). The continuing NW-directed Dent Blanche and Tsaté thrusts accompanied the NW-directed emplacement of the Siviez-Mischabel fold nappe dated at 40-35 Ma by Markley et al. (1998) with $\mathrm{Ar}^{40} / \mathrm{Ar}^{39}$ ages on synkinematic crystallized white mica. The Siviez-Mischabel nappe was thrust during this phase over the Zone Houillère, the Valais calcschists (Sion-Courmayeur nappe) and the Lower Penninic Monte Leone nappe.
E. The spectacular S-verging Mischabel F4 fold (Figs. 3, 11, 14, 15 and stereogram 2 on Fig. 16) exposed north of Zermatt reflects a younger phase of S-directed backfolding conjugate to the frontal NW-directed Penninic and Helvetic thrusts (Escher et al. 1993; Escher and Beaumont 1997). The Mischabel back fold deforms the pre-existing thrusts and schistosities S1-S3 with their associated NW-SE-trending stretching lineation XI, at the southern contact of the SiviezMischabel nappe.

\section{Conclusion}

Table 1 proposes a tentative correlation of the Alpine Structures observed in the Monte Rosa region and the Lepontine gneiss dome. The Early Alpine (Late Cretaceous and Eocene, so-called "Eoalpine") phases of SE-directed subduction, extrusion and accretion of the Sesia, Tsaté, Zermatt-Saas Fee, Monte Rosa and Portjengrat units are inferred from $\mathrm{P}-\mathrm{T}$ estimation, radiometric dating of highpressure metamorphic minerals and the tectonic position of the different units (e.g., Ballèvre and Merle 1993; Reinecke 1998; Gebauer 1999; Amato et al. 1999; Lapen et al. 2003; Bucher et al. 2005). The E-W directed stretching lineation in eclogites of the upper Täsch valley testifies of a phase of high-pressure deformation (Steck 1989). The lineation has the same orientation as an eclogite mineral lineation observed in the Adula nappe (Meyre and Puschnig 1993; Pleuger et al. 2003, 2008; Kurz et al. 2004; Cavargna-Sani et al. 2014) and a Cretaceous E-W extension observed in the Eastern Alps (Ratschbacher 1987). Other deformational structures allowing a better understanding the mechanism of deep underthrusting and extrusion were unfortunately not observed. Normal fault shear structures that testifie of the extrusion oft the Monte Rosa nappe, as documented in other high-pressure metamorphic units such as the Adula nappe (Cavargna-Sani et al. 2014) or in the Tso Morari nappe of the NW Indian Himalaya (Epard and Steck 2008) are missing and probably obliterated by younger ductile deformation. The main ductile deformational structures of the Monte Rosa nappe were created under greenschist to amphibolite facies metamorphism of the Lepontine gneiss dome. The Late Eocene and Oligocene Penninic nappe emplacement is documented by deformational structures, such as schistosities, stretching lineations, shear indicators and folds in ductile deformed rocks at greenschist to amphibolite facies conditions. Radiometric ages indicate that the Barrovian regional metamorphism of the Central Alpine nappe stack occurred during the "Meso-NeoAlpine" orogenic phase between 40 and 18 Ma (Hunziker et al. 1992; Markley et al. 1998; Janots et al. 2009). The 
NW-directed nappe thrusting was followed by high temperature dextral shear and SE-directed Vanzone backfolding and high-temperature and retrograde deformation associated to cooling by uplift and erosion of the rising Lepontine gneiss dome. Dextral transpression in the Central Pennine and Lepontine Alps, the zone of collision of Europe and Adria, was since $33 \mathrm{Ma}$ accompanied by the Insubric Line mantle and crustal derived magmatism and by the frontal NW-directed Helvetic thrusts (Kirschner et al. 1996; Steck 2008; Steck et al. 2013).

Acknowledgments Michel Ballèvre, Robin Lacassin and Yves Gouffon are thanked for their critical reading of the manuscript. The unpublished master thesis works of Anne Crespo-Blanc (1984), AnneMarie Bruttin (1985), Janine Wahli (1985), Pascal Vinard (1986), Samuel Cornaz (1988), Werner Halter (1992), Darco Simič (1992), Suzanne Lobrinus and Pierre Béglé (1994), Michel Jaboyedoff (1994), Mathieu Girard (1995), Elisabeth Carrupt and Micha Schlup (1996), Gilles Tacchini and Olivier Zingg (1999), Vincent Baudraz (2000), Caroline de Meyer (2007), Nicolas Buchs (2013) contributed fundamentally to the knowledge of the studied area.

\section{References}

Amato, J. M., Johnson, C. M., Baumgartner, L. P., \& Beard, B. L. (1999). Rapid exhumation of the Zermatt-Saas ophiolite deduced from high precision $\mathrm{Sm}-\mathrm{Nd}$ and $\mathrm{Rb}-\mathrm{Sr}$ geochronology. Earth and Planetary Science Letters, 171, 425-438.

Angiboust, S., Agard, P., Jolivet, L., \& Beyssac, O. (2009). The Zermatt-Saas ophiolite: the largest $(60-\mathrm{km}$ wide) and deepest (c. $70-80 \mathrm{~km})$ continuous slice of oceanic lithosphere detached from a subduction zone. Terra Nova, 21, 171-180.

Argand, E. (1909). L'exploration géologique des Alpes Pennines Centrales. Bulletin des Laboratoires de Géologie de l'Université de Lausanne 14, p 64.

Argand, E. (1911). Les nappes de recouvrement des Alpes Pennines et leurs prolongements structuraux. Beiträge zur Geologischen Karte der Schweiz, [N.F.] 31, p 26.

Argand, E. (1916). Sur l'arc des Alpes Occidentales. Eclogae Geologicae Helvetiae, 14, 145-204.

Babist, J., Handy, M. R., Konrad-Schmolke, M., \& Hammerschmidt, K. (2007). Precollisional, multistage exhumation of subducted continental crust: the Sesia zone, Western Alps. Tectonics,. doi:10.1029/2005TC001927.

Ballèvre, M., \& Merle, O. (1993). The Combin fault: compressional reactivation of a Late Cretaceous-Early Tertiary detachment fault in the Western Alps. Schweizerische Mineralogische und Petrographische Mitteilungen, 73, 205-227.

Barnicoat, A. C., \& Fry, N. (1986). High-pressure metamorphism of the Zermatt-Saas ophiolite zone, Switzerland. Journal of the Geological Society of London, 143, 607-618.

Bearth, P. (1939). Über den Zusammenhang von Monte Rosa- und Bernhard-Decke. Eclogae geologicae Helvetiae, 32/1.

Bearth, P. (1952). Geologie und Petrographie des Monte Rosa. Beiträge zur geologischen Karte der Schweiz, [N.F.] 96, p 94.

Bearth, P. (1953). Map sheet 1348: Zermatt. Wabern, Schweiz: Geologischer Atlas der Schweiz, Bundesamt für Landestopographie, Landesgeologie.

Bearth, P. (1954a). Map sheet 1329: Saas, Geologischer Atlas der Schweiz 1329, Bundesamt für Landestopographie, Landesgeologie, Wabern, Schweiz.
Bearth, P. (1954b). Map sheet 1349: Monte Moro, Geologischer Atlas der Schweiz 1329, Bundesamt für Landestopographie, Landesgeologie, Wabern, Schweiz.

Bearth, P. (1956). Geologische Beobachtungen im Grenzgebiet der Lepontinischen und Penninischen Alpen. Eclogae Geologicae Helvetiae, 49(2), 279-290.

Bearth, P. (1957a). Die Umbiegung von Vanzone. Eclogae Geologicae Helvetiae, 50(1), 161-170.

Bearth, P. (1957b). Erläuterungen zu Blatt Saas und Monte Moro. Geologischer Atlas der Schweiz, 1329 und 1349, Bundesamt für Landestopographie, Landesgeologie, Wabern, Schweiz.

Bearth, P. (1958). Über einen Wechsel der Mineralfazies in der Wurzelzone des Penninikums. Schweizerische Mineralogische und Petrographische Mitteilungen, 38(2), 363-373.

Bearth, P. (1962). Versuch einer Gliederung der alpinmetamorphen Serien der Westalpen. Schweizerische Mineralogische und Petrographische Mitteilungen, 42(1), 127-137.

Bearth, P. (1964). Map sheet 1328: Randa, Geologischer Atlas der Schweiz 1329, Bundesamt für Landestopographie, Landesgeologie, Wabern, Schweiz.

Bearth, P. (1967). Die Ophiolite der Zone von Zermatt-Saas Fee. Beiträge zur geologischen Karte der Schweiz, [N.F.] 132, p 130.

Bearth, P. (1972). Map sheet 1309: Simplon, Geologischer Atlas der Schweiz, Bundesamt für Landestopographie, Landesgeologie, Wabern, Schweiz

Bearth, P. (1973). Gesteins- und Mineralparagenesen aus den Ophioliten von Zermatt. Schweizerische Mineralogische und Petrographische Mitteilungen, 53(2), 299-334.

Bearth, P. (1978). Map sheet 1308: Saas, Geologischer Atlas der Schweiz 1329, Bundesamt für Landestopographie, Landesgeologie, Wabern, Schweiz.

Beccaluva, L., Bigioggero, B., Chiesa, S., Colombo, A., Gatto, G. O., Gregnanin, A., et al. (1983). Post collisional orogenic dike magmatism in the Alps. Memorie Società geologica Italia, 26, 341-359.

Bernoulli, D., Manatschal, G., Desmurs, L., \& Müntener, R. (2003). Where did Gustav Steinmann see trinity ? Back to the roots of an Alpine ophiolite concept. Geological Society of America, Special Paper, 373, 93-110.

Bigioggero, B., Boriani, A., Colombo, A., Ferrara, G., Tunesi, A., \& Tonarini, S. (1981). Eta e caratteri petrochimici degli ortogneiss della zona Moncucco-Orselina nell'area Ossolana. Rendiconti della Societa Italiana di Mineralogia e Petrologia, 38, 207-218.

Bill, M., Bussy, F., Cosca, M., Masson, H., \& Hunziker, J. (1997). Highprecision $\mathrm{U}-\mathrm{Pb}$ and ${ }^{40} \mathrm{Ar} /{ }^{39} \mathrm{Ar}$ dating of an Alpine ophiolite (Gets nappe, French Alps). Eclogae Geologicae Helvetiae, 90(1), 43-54.

Bucher, K., Dal Piaz, G.V., Martinotti, G. Oberhänsli, R., Polino, R. (2004). Map sheet 1347: Matterhorn, Geologischer Atlas der Schweiz, Bundesamt für Landestopographie, Landesgeologie, Wabern, Schweiz.

Bucher, K., Yvonne, F., De Capitani, C., \& Grapes, R. (2005). Blueschists, eclogites, and decompressional assemblages of the Zermatt-Saas ophiolite: high-pressure metamorphism of subducted Tethys lithosphere. American Mineralogist, 90, 821-835.

Bussy, F., Sartori, M., \& Thélin, P. (1996). U-Pb zircon dating in the middle Penninic basement of the Western Alps (Valais, Switzerland). Schweizerische Mineralogische und Petrographische Mitteilungen, 76(1), 81-84.

Bussy, F., Venturini, G., Hunziker, J., \& Martinotti, G. (1998). U-Pb ages of magmatic rocks of the western Austroalpine DentBlanche-Sesia unit. Schweizerische Mineralogische und Petrographische Mitteilungen, 78(1), 163-168.

Butler, J. P., Beaumont, C., \& Jamieson, R. A. (2013). The Alps 1: a working geodynamic model for burial and exhumation of (ultra)high-pressure rocks in Alpine type orogens. Earth and Planetary Science Letters, 377-378, 114-131. 
Campani, M. (2011). Temporal and spatial evolution of a synorogenic extensional system: the Simplon Fault Zone (Central Alps). Ph.D. dissertation No 18461, ETH Zürich.

Carrupt, E. (2003). New stratigraphic, structural and geochemical data from the Val Formazza-Binntal area (Central Alps). Mémoires de Géologie (Lausanne), 41, p 117.

Carrupt, E., \& Schlup, M. (1998). Métamorphism et tectonique du versant sud du Val Bognanco (Pennique, Alpes italiennes). Bulletin de la Société Vaudoise de Sciences Naturelles, 81(1), 29-59.

Cartwright, I., \& Barnicoat, A. C. (2002). Petrology, geochronology, and tectonics of shear zones in the Zermatt-Saas and Combin zones of the Western Alps. Journal of Metamorphic Geology, 20, 263-281.

Cavargna-Sani, M., Epard, J-L., \& Steck, A. (2014). Structure, geometry and kinematics of the northern Adula nappe (Central Alps). Swiss Journal of Geosciences, 107(2-3), 135-156.

Chemenda, A. I., Mattauer, M., Malavielle, J., \& Bokun, A. N. (1995). A mechanism for syn-collisional rock exhumation and associated normal faulting: results from physical modelling. Earth and Planetary Science Letters, 132, 225-232.

Colombi, A. (1989). Métamorphisme et géochimie des roches mafiques des Alpes ouest-centrales (géoprofil Viège-Domodossola-Locarno). Mémoires de géologie (Lausanne) 4, p 216.

Dal Piaz, G. V. (1992). Le Alpi dal M. Bianco al Lago Maggiore. Guide Geologiche Regionale (Vol. 3). Roma: Società geologiche Italiana.

Dal Piaz, G. V. (2001). Geology of the Monte Rosa massif: historical review and personal comments. Schweizerische Mineralogische und Petrographische Mitteilungen, 81, 275-303.

Dal Piaz, G. V., Cortiana, G., Del Moro, A., Martin, S., Pennacchioni, G., \& Tartarotti, P. (2001). Tertiary age and paleostructural inferences of the eclogitic imprint in the Austroalpine outliers and Zermatt-Saas ophiolite, western Alps. International Journal of Earth Science, 90, 668-684.

Dal Piaz, G. V., Hunziker, J. C., \& Martinotti, G. (1972). La zone Sesia-Lanzo e l'evoluzione tettonico-metamorphica delle Alpi nordoccidentali interne. Memorie dell Società geologica Italiana, 11, 433-466.

De Meyer, M. C., Baumgartner, L. P., Beard, B. L., \& Johnson, C. M. (2014). Rb-Sr ages from phengite inclusions in garnets from high pressure rocks of the Swiss Western Alps. Earth and Planetary Science Letters, 395, 205-216.

Duchène, S., Blichert-Toft, J., Luais, B., Télouk, P., Lardaux, J. M., \& Albarède, F. (1997). The Lu-Hf dating of garnets and the ages of the Alpine high-pressure metamorphism. Nature, 387, 586-588.

Ellenberger, F. (1953). La série du Barrhorn et les rétrocharriages penniques. Comptes rendus de l'Académie des Sciences de Paris, 236, 218-220.

Engi, M., Bousquet, R., \& Berger, A. (2004). Explanatory notes to the map; Metamorphic structure of the Alps, Central Alps. Mitteilungen der Österreichischen Mineralogischen Gesellschaft, 149, 157-173.

Engi, M., Scherrer, N. C., \& Burri, T. (2001). Metamorphic evolution of pelitic rocks of the Monte Rosa nappe: constraints from petrology and single grain monazite age data. Schweizerische Mineralogische und Petrographische Mitteilungen, 81, 305-328.

Epard, J. L., \& Escher, A. (1996). Transition from basement to cover: a geometric model. Journal of Structural Geology, 18, 533-548.

Epard, J. L., \& Steck, A. (2008). Structural development of the Tso Marari ultra-high pressure nappe of the Ladakh Himalaya. Tectonophysics, 451, 242-264.

Escher, A. (1988). Structure de la nappe du Grand Saint-Bernard entre le val de Bagnes et les Mischabel. Rapports géologiques du Service hydrogéologique et géologique national 7, p 26.

Escher, A., \& Beaumont, C. (1997). Formation, burial and exhumation of basement nappes at crustal scale: a geometric model based on the western Swiss-Italian Alps. Journal of Structural Geology, 19, 955-974.

Escher, A., Hunziker, J., Marthaler, M., Masson, H., Sartori, M., \& Steck, A. (1997). Geologic framework and structural evolution of the western Swiss-Italian Alps. In O. A. Pfiffner, P. Lehner, P. Heitzmann, S. Mueller, \& A. Steck (Eds.), Deep structure of the Swiss Alps: results of NRP (Vol. 20, pp. 205-221). Basel: Birkhäuser Verlag.

Escher, A., Masson, H., \& Steck, A. (1988). Coupes géologiques à travers la partie centrale des Alpes occidentales suisses. Rapports géologiques du Service hydrologique et géologique national Suisse, 2, 1-11.

Escher, A., Masson, H., \& Steck, A. (1993). Nappe geometry in the Western Swiss Alps. Journal of Structural Geology, 15, 501-509.

Frank, E. (1983). Alpine metamorphism of calcareous rocks along a cross-section in the Central Alps: occurence and breakdown of muscovite, margarite and paragonite. Schweizerische Mineralogische und Petrographische Mitteilungen, 63, 37-93.

Frey, M., Desmons, J., \& Neubauer, F. (1999). The new metamorphic map of the Alps. Schweizerische Mineralogische und Petrographische Mitteilungen, 79, 1-230.

Frey, M., Hunziker, J. C., Jäger, E., \& Stern, W. B. (1983). Regional distribution of white K-mica polymorphs and their phengite content in the Central Alps. Contributions to Mineralogy and Petrology, 83, 185-197.

Frey, M., Hunziker, J. C., O’Neil, J. R., \& Schwander, H. W. (1976). Equilibrium-disequilibrium relations in the Monte Rosa granite, western Alps: petrological, $\mathrm{Rb}-\mathrm{Sr}$ and stable isotope data. Contributions to Mineralogy and Petrology, 55, 147-179.

Froitzheim, N. (2001). Origin of the Monte Rosa nappe in the Pennine Alps: a new working hypothesis. Geological Society of America, Bulletin, 113, 604-614.

Ganguin, J. (1988). Contribution à la characterisation du métamorphisme polyphasé de la Zone de Zermatt-Saas Fee. Ph.D. Thesis, ETH Zürich $N^{\circ} 8731$.

Gebauer, D. (1999). Alpine geochronology of the Central and Western Alps. Schweizerische Mineralogische und Petrographische Mitteilungen, 79, 191-208.

Genier, F., Epard, J. L., Bussy, F., \& Magna, T. (2008). Lithostratigraphy and $\mathrm{U}-\mathrm{Pb}$ zircon dating in the overturned limb of the Siviez-Mischabel nappe; a new key for middle Penninic nappe geometry. Swiss Journal of Geosciences, 101, 431-452.

Gosso, G., Dal Piaz, G.V., Piovano, V. \& Polino, R. (1979). High pressure implacement of early-alpine nappes, postnappe deformations and structural levels. Memorie della Società Geologica Italiana, 32, p 15.

Grujic, D., \& Mancktelow, N. S. (1996). Structure of the northern Maggia and Lebendun nappes, Central Alps, Switzerland. Eclogae Geologicae Helvetiae, 89, 461-504.

Güller, A. (1947). Zur Geologie der südlichen Mischabel- and der Monte Rosa-Gruppe. Eclogae Geologicae Helvetiae, 40, 41-161.

Handy, M. R., Schmid, S. M., Bousquet, R., Kissling, E., \& Bernoulli, D. (2010). Reconciliation plate-tectonic reconstructions of Alpine Tethys with the geological-geophysical record of spreading and subduction in the Alps. Earth Science Reviews, 102, 121-158.

Hermann, F. (1937). Carta geologica delle Alpi nord-occidentali alla scala 1:200,000, con note illustrative e carta strutturale alla scala 1:750,000. Tipographia Allegretti di Campi, Milano.

Herwartz, D., Münker, C., Scherer, E. E., Nagel, T. J., Pleuger, J., \& Froitzheim, N. (2008). Lu-Hf garnet geochronology of eclogites from the Balma Unit (Pennine Alps): implications for Alpine paleotectonic reconstructions. Swiss Journal of Geosciences, 101, S173-S189. 
Higgins, M.W. (1971). Cataclastic rocks. Geological Survey Professional Paper, 687, p 97, Washington, D.C.

Huang, T. K. (1936). Etude géologique de la region WeissmiesPortjengrat (Valais). Bulletin de la Société Neuchâteloise des Sciences Naturelles, 60, 3-76.

Huber, M., Ramsay, J., \& Simpson, C. (1980). Deformation in the Maggia and Antigorio nappes. Lepontine Alps. Eclogae geologicae Helvetiae, 73(2), 593-606.

Hunziker, J. C. (1969). Rb/Sr Altersbestimmungen aus den Wallisser Alpen, Hellglimmer und Gesammtgesteinswerte. Eclogae Geologicae Helvetiae, 62, 527-542.

Hunziker, J. C., \& Bearth, P. (1969). Rb-Sr-Altersbestimmungen aus den Wallisser Alpen, Biotitalterswerte und ihre Bedeutung für die Abkühlungsgeschichte der alpinen Metamorphose. Eclogae Geologicae Helvetiae, 62, 205-222.

Hunziker, J.C., Desmons, J. \& Hurford, A.J. (1992). Thirty-two years of geochronological work in the central and Western Alps: a review on seven maps. Mémoires de géologie (Lausanne), 13, p 59.

Hurford, A. J. (1986). Cooling and uplift patterns in the Lepontine Alps, south-central Switzerland, and an age of vertical movement on the Insubric fault line. Contributions to Mineralogy and Petrology, 93, 413-427.

Jaboyedoff, M., Béglé, P., \& Lobrinus, S. (1996). Stratigraphie et evolution structural de la zone de Furgg, au front de la nappe du Mont-Rose. Bulletin de la Société Vaudoise des Sciences Naturelles, 84(2), 191-210.

Janots, E., Engi, M., Rubatto, D., Berger, A., Gregory, C., \& Rahn, M. (2009). Metamorphic rates in collisional orogeny from in situ allanite and monazite dating. Geology, 37(1), 11-14.

Keller, L. M., Hess, M., Fügenschuh, B., \& Schmid, S. M. (2005). Structural and metamorphic evolution SW of the Simplon line. Eclogae Geologicae Helvetiae, 98, 19-49.

Keller, L. M., \& Schmid, S. M. (2001). On the kinematics of shearing near the top of the Monte Rosa nappe and the nature of the Furgg zone in Val Loranco (Antrona valley, N. Italy): tectonometamorphic and paleogeographical consequences. Schweizerische Mineralogische und Petrographische Mitteilungen, 81, 347-367.

Kirschner, D. L., Cosca, M. A., Masson, H., \& Hunziker, J. (1996). Staircase 40Ar/39Ar spectra of fine-grained white mica: timing and duration of deformation and empirical constraints on argon diffusion. Geology, 24(8), 747-750.

Klein, J. A. (1978). Post nappe folding southeast of the Mischabel Rückfalte (Pennine Alps) and some aspects of the associated metamorphism. Leidse Geologiske Mededeleser, 51, 233-312.

Konrad-Schmolke, M., Babist, J., Handy, M. R., \& O'Brian, P. J. (2006). The physico-chemical properties of a subducted slab from garnet zonation patterns (Sesia zone, Western Alps). Journal of Petrology, 47, 2123-2148.

Kurz, W., Jansen, E., Hundenborn, R., Pleuger, J., Schäfer, W., \& Unzog, W. (2004). Microstructures and crystallographic preferred orientations of omphacite in Alpine eclogites: implications for the exhumation of (ultra-) high-pressure units. Journal of Geodynamics, 37, 1-55.

Lacassin, R. (1984). Etude des mecanismes de deformation dans le versant nord de la nappe du Mont Rose (Alpes Suisses) et les relations avec les grands chevauchements. Ph.D. thesys, Université des Sciences et Techniques du Languedoc, Montpellier, $\mathrm{p} 241$.

Lacassin, R. (1989). Plate-scale kinematics and compatibilty of crustal shear zones in the Alps. In M. P. Coward, D. Diedtrich, \& R. G. Park (Eds.), Alpine tectonics (Vol. 45, pp. 339-352). London: Geological Society Special Publication.

Lacassin, R., \& Mattauer, M. (1985). Kilometre-scale sheath fold at Mattmark and implications for transport direction in the Alps. Nature, 316(6022), 739-742.
Laduron, D. (1976). L'antiforme de Vanzone. Etude pétrographique et structural dans la Valle Anzasca (Prov. De Novara, Italie). Ph.D. Thesis, Université de Louvain.

Laduron, D., \& Merlin, M. (1974). Evolution structurale et métamorphique de l'antiforme de Vanzone (Valle Anzasca, Provincia di Novara, Italie). Bulletin de la Société géologique de France, $16,264-265$.

Lapen, B. J., Johnson, C. M., Baumgartner, L. P., Mahlen, N. J., Beard, B. L., \& Amato, J. M. (2003). Burial rates during prograde metamorphism of an ultra-high-pressure terrane: an example from Lago di Cignana, Western Alps, Italy. Earth and Planetary Science Letters, 215, 57-72.

Laubscher, H., \& Bernoulli, D. (1982). History and deformation of the Alps. In K. J. Hsü (Ed.), Mountain building processes (pp. 169-180). London: Academic Press.

Liati, A., \& Froitzheim, N. (2006). Assessing the Valais ocean, Western Alps: U-Pb SHRIMP zircon geochronology of eclogite in the Balma unit, on top of the Monte Rosa nappe. European Journal of Mineralogy, 18, 299-308.

Liati, A., Froitzheim, N., \& Fanning, C. M. (2005). Jurassic ophiolites within the Valais domain of the Western and central Alps: geochronological evidence for re-rifting of oceanic crust. Contributions to Mineralogy and Petrology, 149, 446-461.

Liati, A., Gebauer, D., Froitzheim, N., \& Fanning, C. M. (2001). U-Pb SHRIMP geochronology of an amphibolitized eclogite and an orthogneiss from the Furgg zone (WesternAlps) and implications for its geodynamic evolution. Schweizerische Mineralogische und Petrographische Mitteilungen, 81, 379-393.

Mancktelow, N. S. (1985). The Simplon Line: a major displacement zone in the Western Lepontine Alps. Eclogae Geologicae Helvetiae, 78, 73-96.

Mancktelow, N. S. (1990). The Simplon Fault Zone. Beiträge zur geologischen Karte der Schweiz, [N.F.] 163.

Mancktelow, N. S. (1992). Neogene lateral extension during convergence in the Central Alps: evidence from interrelated faulting and backfolding around the Simplonpass (Switzerland). Tectonophysics, 215, 295-317.

Mancktelow, N. S. (2008). Tectonic pressure; theoretical concepts and modelled examples. Lithos, 103, 149-177.

Marchant, R., Steck, A., Escher, A., Levato, L., Masson, H., Olivier, R., et al. (1993). An interpretation of the deep seismic lines from the Penninic Alps of Valais (Switzerland). Bulletin de la Société géologique de France, 164, 395-414.

Markley, M. J., Teyssier, C., Cosca, M. A., Caby, M. A., Hunziker, J. C., \& Sartori, M. (1998). Alpine deformation and ${ }^{40} \mathrm{Ar} /{ }^{39} \mathrm{Ar}$ geochronology of synkinematic white mica in the SiviezMischabel Nappe, western Pennine Alps, Switzerland. Tectonics, 17, 407-425.

Marthaler, M. (1984). Géologie des unites penniques entre le Val d'Anniviers et le val de Tourtemagne (Valais, Suisse). Eclogae Geologicae Helvetiae, 77(2), 395-448.

Marthaler, M., Sartori, M., Escher, A. \& Meisser, N. (2008). Feuille 1307 Vissoie. Atlas géologique Suisse 1:25,000, Carte et Notice explicative 122.

Marthaler, M., \& Stampfli, G. (1989). Les schistes lustres à ophiolites de la nappe du Tsaté: un ancient prism d'accretion issu de la marge active apulienne. Bulleten Suisse de minéralogie et pétrographie, 69(2), 211-216.

Masson, H. (2002). Ophiolites and other (ultra) basic rocksfrom the West-Central Alps: new data for a puzzée. Bulletin de la Société Vaudoise des Sciences Naturelles, 88, 263-276.

Maxelon, M., \& Mancktelow, N. S. (2005). Three-dimensional geometry and tectonostratigraphy of the Pennine zone, Central Alps, Switzerland and Northern Italy. Earth Science Reviews, 71, 171-227. 
Meyer, J. (1983). Mineralogie und Petrologie des Allalingabbros. Ph.D. thesis, Basel.

Meyre, C., \& Puschnig, A. R. (1993). High pressure metamorphism and deformation at Trescolmen, Adula nappe, Central Alps. Schweizerische Mineralogische und Petrographische Mitteilungen, 73, 277-284.

Milnes, A. G., Greller, M., \& Müller, R. (1981). Sequence and style of major post- nappe structures. Simplon-Pennine Alps. Journal of Structural Geology, 3(4), 411-420.

Monjoie, P., Bussy, F., Schaltegger, U., Mulch, A., Lapierre, H., \& Pfeifer, H. R. (2007). Contrasting magma types and timing in the Permian layered mafic complex of Mont Collon (Western Alps, Valais, Switzerland): evidence from $\mathrm{U} / \mathrm{Pb}$ zircon and ${ }^{40} \mathrm{Ar} /{ }^{39} \mathrm{Ar}$ amphibole dating. Swiss Journal of Geosciences, 100, 125-135.

Müller, R. (1983). Die Struktur der Mischabelfalte (Penninische Alpen). Eclogae geologicae Helveticae, 76(2), 391-416.

Negro, F., Bousquet, R., Vils, F., Pellet, C.-M., \& Hänggi-Schaub, J. (2013). Thermal structure and metamorphic evolution of the Piemont-Ligurian metasediments in the northern Western Alps. Swiss Journal of Geosciences, 106(1), 63-78.

Oberhänsli, R. (Ed.) (2004). Metamorphic structure of the Alps, Explanatory notes and map, Scale 1:100,0000. Mitteilungen der Österreichischen mineralogischen Gesellschaft, 149 (pp. 115-226).

Partzsch, J.H. (1998). Tectono-metamorphic evolution of the middle Adula nappe, Central Alps, Switzerland, PhD thesis, Universität Basel.

Pawlig, S., \& Baumgartner, L. (2001). Geochemistry of a talckyanite-chloritoid shear zone within the Monte Rosa granite, Val d'Ayas, Italy. Schweizerische Mineralogische und Petrographische Mitteilungen, 81, 329-346.

Petrini, K. \& Podladchikov, Y.Y. (2000). Lithospheric pressure-depth relationship in compressive regions of thickened crust. Journal of Metamorphic Geology, 18, 67-78.

Pettke, T., Diamond, L. W., \& Villa, I. M. (1999). Mesothermal gold veins and metamorphic devolatilization in the northwestern Alps: the temporal link. Geology, 27, 641-644.

Pfeifer, H.-R., Colombi, A., Ganguin, J., Hunziker, J. C., Oberhänsli, R., \& Santini, L. (1991). Relicts of high-pressure metamorphism in different lithologies of the Central Alps, an updated inventory. Schweizerische Mineralogische und Petrographische Mitteilungen, 71, 441-451.

Platt, J. P. (1986). Dynamics of orogenic wedges and the uplift of high-pressure metamorphic rocks. Geological Society of America, Bulletin, 97, 1037-1053.

Pleuger, J., Froitzheim, N. \& Jansen, E. (2005). Folded continental and oceanic nappes on the southern side of Monte Rosa (western Alps, Italy): anatomy of a double collision suture. Tectonics, 24, TC 4013, doi:10.1029/2004TC001737.

Pleuger, J., Hundenborn, N., Kremer, K., Babinka, S., Kurz, W., Jansen, E., \& Froitzheim, N. (2003). Structural evolution of Adula nappe, Misox zone, and Tambo nappe in the San Bernardino area: constraints for the exhumation of the Adula eclogites. Mitteilungen der Österreichischen Geologischen Gesellschaft, 94, 99-122.

Pleuger, J., Nagel, T. J., Walter, J. M., Jens, M., Jansen, E., \& Froitzheim, N. (2008). On the role and importance of orogenparallel and -perpendicular extension, transcurrent shearing, and backthrusting in the Monte Rosa nappe and the Southern Steep Belt of the Alps (Penninic zone, Switzerland and Italy). Geological Society of America, Special Paper, 298, 251-280.

Ramsay, J. G. (1967). Folding and fracturing of rocks. New York: McGraw-Hill.

Ratschbacher, L. (1987). Strain, rotation, and translation of Austroalpine cover nappes. In H. W. Flügel \& P. Faupl (Eds.),
Geodynamics of the Eastern Alps (pp. 237-243). Vienna: Deuticke.

Reddy, S. M., Weeler, J., \& Kliff, R. A. (1999). The geometry and timing of orogenic extension: an example from the western Italian Alps. Journal of Metamorphic Geology, 17, 573-589.

Reinecke, T. (1998). Prograde high- to ultrahigh-pressure metamorphism and exhumation of oceanic sediments at Lago Cignana, Zermatt-Saas Fee zone, Western Alps. Lithos, 42, 147-189.

Reinhardt, B. (1966). Monte Rosa-Zone, Sesia-Zone und Canavese im Gebiet zwischen Valle d'Ossola und Valle Loana (Prov. Novara). Schweizerische Mineralogische und Petrographische Mitteilungen, 46, 553-678.

Ring, U., \& Merle, O. (1992). Forethrusting, backfolding, and lateral gravitational escape in the northern part of the Western Alps (Monte Rosa region). Geological Society of America, Bulletin, 104, 901-914.

Romer, R., Schärer, U., \& Steck, A. (1996). Alpine and pre-Alpine magmatism in the root zone of the Western Alps. Contributions to Mineralogy and Petrology, 123, 138-158.

Rubatto, D., Gebauer, D., \& Compagnoni, R. (1999). Dating of eclogite facies zircons: the age of Alpine metamorphism in the Sesia-Lanzo zone (western Alps). Earth and Planetary Science Letters, 167, 141-158.

Rubatto, D., Gebauer, D., \& Fanning, M. (1998). Jurassic and Eocene subduction of the Zermatt- Saas-Fee ophiolites: implications for the geodynamic evolution of the Central and Western Alps. Contributions to Mineralogy and Petrology, 132, 269-287.

Rubatto, D., Herrmann, J., Berger, A., \& Engi, M. (2009). Protracted fluid-induced melting during Barrovian metamorphism in the Central Alps. Contributions to Mineralogy and Petrology, 158, 703-722.

Ruffet, G., Gruau, G., Ballèvre, M., Féraud, G., \& Philippot, P. (1997). Rb-Sr und 40Ar-39Ar laser probe dating of high-pressure phengites from the Sesia zone (Western Alps): underscoring of excess argon and new age constraints on the high-pressure metamorphism. Chemical Geology, 141, 1-18.

Sartori, M. (1987). Structure de la zone du Combin entre les Diablons et Zermatt (Valais). Eclogae Geologicae Helvetiae, 80(3), 789-814.

Sartori, M. (1990). L'unité du Barrhorn (Zone pennique, Valais, Suisse). Mémoire de Géologie (Lausanne) 6, p 156.

Sartori, M., Gouffon, Y., \& Marthaler, M. (2006). Lithostratigraphie des unites briançonnaises en Valais. Swiss Journal of Geosciences, 99(3), 363-408.

Schardt, H. (1903). Note sur le profil géologique et la tectonique du massif du Simplon comparée aux travaux antérieurs. Eclogae Geologicae Helvetiae, 8, 173-200.

Schärer, U., Cosca, M., Steck, A., \& Hunziker, J. (1996). Termination of major ductile strike-slip shear and differential cooling along the Insubric line (Central Alps). Earth and Planetary Science Letters, 142, 331-351.

Schmalholz, S.M. \& Podladchikov, Y.Y. (2013). Tectonic overpressure in weak crustal shear zones and implications for the exhumation of high pressure rocks. Geophysical research Letters, 40(10), 1984-1988.

Schmid, S., Aebli, H. R., Heller, F., \& Zingg, A. (1989). The role oft the Periadriatic line in the tectonic evolution of the Alps. In M. P. Coward, D. Diedtrich, \& R. G. Park (Eds.), Alpine tectonics (Vol. 45, pp. 153-173). London: Geological Society Special Publication.

Soom, M. (1990). Abkühlung- und Hebungsgeschichte der Externmassive und der Penninischen Decken beidseits der SimplonRhone-Linie seit dem Oligocaen: Spaltspurdatierungen an Apatit/Zircon und K-Ar-Datierungen an Biotit/Muskowit (Westliche Zentralalpen). Ph.D. thesis, University of Bern, $\mathrm{p} 119$. 
Stampfli, G. M., Mosar, J., Favre, P., Pillevuit, A., \& Vannay, J.-C. (2001). Permo-Mesozoic evolution of the western Tethys realm: the Neo-Tethys East Mediterranian basin connection. In P. A. Ziegler, W. Cavazza, A. H. F. Robertson, \& S. CrasquinSoleau (Eds.), Peri-Tethys Memoir 6: Peri-Tethyan Rift/Wrench basins and passive margins (Vol. 186, pp. 51-98). Paris: Mémoires du Museum National d'Histoire Naturelle.

Steck, A. (1980). Deux directions principales de flux synmétamorphique dans les Alpes centrales. Bulletin de la Société Vaudoise de Sciences naturelles, 75(358), 141-149.

Steck, A. (1984). Structures de déformations tertiaires dans les Alpes centrales (transversale Aar-Simplon-Ossola). Eclogae Geologicae Helvetiae, 77, 55-100.

Steck, A. (1989). Structures des deformations alpines dans la region de Zermatt. Schweizerische Mineralogische und Petrographische Mitteilungen, 69, 205-210.

Steck, A. (1990). Une carte des zones de cisaillement ductile des Alpes centrales. Eclogae Geologicae Helvetiae, 83, 603-627.

Steck, A. (2008). Tectonics of the Simplon massif and Lepontine gneiss dome: deformation structures due to collision between the underthrusting European plate and the Adriatic indenter. Swiss Journal of Geosciences, 101, 515-546.

Steck, A., Bigioggero, B., Dal Piaz, G.V., Escher, A., Martinotti, G. \& Masson, H. (1999). Carte géologique des Alpes de Suisse occidentale, 1:100,000, Carte géologique spéciale $N^{\circ} 123$, Service Hydrologique et Géologique National (Berne).

Steck, A., Della Torre, F., Keller, F., Pfeifer, H. R., Hunziker, J., \& Masson, H. (2013). Tectonics of the Lepontine Alps: ductile thrusting and folding in the deepest tectonic levels of the Central Alps. Swiss Journal of Geosciences, 206, 427-450.

Steck, A., Epard, J.L., Escher, A., Gouffon, Y. \& Masson, H. (2001). Notice explicative de la carte géologique des Alpes de suisse occidentale 1:100,000. Carte géologique spéciale $N^{\circ} 123$. Office fédéral des Eaux et de la Géologie (Berne).

Steck, A., Epard, J.-L., Escher, A., Lehner, P., Marchant, R., \& Masson, H. (1997). Geological interpretation of the seismic profiles through Western Switzerland: Rawil (W1), Val d'Anniviers (W2), Mattertal (W3), Zmutt-Zermatt-Findelen (W4) and Val de Bagnes (W5). In O. A. Pfiffner, P. Lehner, P. Heitzmann, S. Mueller, \& A. Steck (Eds.), Deep structure of Swiss Alps: results of NRP 20 (pp. 241-250). Basel: Birkhäuser.
Steck, A., \& Hunziker, J. (1994). The Tertiary structural and thermal evolution of the Central Alps - compressional and extensional structures in an orogenic belt. Tectonophysics, 238, 229-254.

Steck, A., Ramsay, J. G., Milnes, A. G., \& Burri, M. (1979). Compte rendu de l'excursion de la société Géologique suisse et la société de Minéralogie et Pétrographie en Valais et en Italie nord du 2 au 5 octobre 1978. Eclogae Geologicae Helvetiae, 72(1), 287-311.

Surace, I. R., Clauer, N., Thélin, P., \& Pfeifer, H. R. (2011). Structural analysis, clay mineralogy and $\mathrm{K}-\mathrm{Ar}$ dating of fault gouges from Centovalli Line (Central Alps) for reconstruction of their recent activity. Tectonophysics, 510, 80-93.

Tektonische Karte der Schweiz, 1:500,000 (2005). Federal Office for Water and Geology. Bern, Switzerland.

Trümpy, R. (1980). Geology of Switzerland: a guide book. Part A: an outline of the geology of Switzerland (p. 104). Wepf, Basel, New York: Schweizerische geologische Kommission.

Ulmer, P., \& Trommsdorff, V. (1995). Serpentine stability to mantle depths and subduction-related magmatism. Sciences, 268, $858-861$.

Vannay, J.-C., \& Allemann, R. (1990). La zone pièmontaise dans le Haut-Valtournanche Val d'Aoste, Italie. Eclogae Geologicae Helvetiae, 83, 21-39.

Venturini, G. (1995). Geology, Geochemistry and Geochronology oft the inner central Sesia Zone (Western Alps-Italy). Mémoires de Géologie, Lausanne 25, p 148.

Wenk, E., \& Keller, F. (1969). Isograden in Amphibolitserien der Zentralalpen. Schweizerische Mineralogische und Petrographische Mitteilungen, 49, 157-191.

Wetzel, R. (1972). Zur Petrographie und Mineralogie der Furgg-Zone (Monte Rosa Decke). Schweizerische Mineralogische und Petrographische Mitteilungen, 52(2), 161-236.

Zingg, A., Handy, M. R., Hunziker, J. C., \& Schmid, S. M. (1990). Tectonometamorphic history oft he Ivrea zone and ist relatioship to the crustal evolution oft he Southern Alps. Tectonophysics, 182, 169-192.

Zingg, A., \& Hunziker, J. C. (1990). The age of movements along the Insubric Line West of Locarno (northern Italy and southern Switzerland). Eclogae Geologicae Helvetiae, 83(3), 629-644.

Zwingmann, H., \& Mancktelow, N. (2004). Timing of Alpine fault gouges. Earth and Planetary Science Letters, 223, 415-425. 